\title{
Human Body Fluid Ions In colchicine complexes ESI MS, MADLI MS, Spectroscopic, DFT Studies and Fungicidal Activity of colchicine complexes With Sodium, Potassium, Magnesium and calcium carbonates and Sulphates
}

\author{
Joanna Kurek ${ }^{*}$, Grażyna Bartkowiak ${ }^{2}$, Wojciech Jankowski ${ }^{3}$, Patrycja \\ Kwaśniewska-Sip ${ }^{4}$, Grzegorz Schroeder ${ }^{5}$, Marcin Hoffmann ${ }^{6}$, Grzegorz Cofta ${ }^{7}$, \\ Piotr Barczyński ${ }^{8}$ \\ Faculty of Chemistry, Adam Mickiewicz University, Umultowska 89b, 61-614 Poznań, Poland \\ ${ }^{4,7}$ Institute of Chemical Wood Technology, University of Life Science, Wojska Polskiego 38/42, 60-037
}

Poznań, Poland

Abstract: Colchicine is an alkaloid characterised by good water solubility. After administration of colchicine as a medicine for example for the treatment of gout, colchicine probably forms some more or less stable structures with cations and/or anions present in human body fluid. The colchicine complexes with $\mathrm{Na}^{+}, \mathrm{K}^{+} \mathrm{Mg}^{2+}$ and $\mathrm{Ca}^{2+}$ cations of sulphates and carbonates have been synthesized and studied by ESI MS, MALDI MS, ${ }^{1} \mathrm{H}$ and ${ }^{13} \mathrm{C}$ NMR, FT IR DFT calculations and also have been tested against fungicidal activity. Salts of good solubility in water have been chosen, like $\mathrm{Na}_{2} \mathrm{SO}_{4}, \mathrm{~K}_{2} \mathrm{SO}_{4}, \mathrm{Na}_{2} \mathrm{CO}_{3}, \mathrm{~K}_{2} \mathrm{CO}_{3}, \mathrm{MgSO}_{4}$ and $\mathrm{CaSO}_{4}$. It has been shown that colchicine forms stable complexes of 1:1 stoichiometry with monovalent and divalent metal cations. For $\mathrm{K}^{+}$and $\mathrm{Na}^{+}$cations also formation of 2:1 stoichiometry complexes has been detected. Colchicine with sodium sulphate forms much more complicated structures of 1:2:1 and 2:2:1 stoichiometry in which sulphate anion is involved. Colchicine complexes have fungicidal activity.

Keywords - complexes of colchicine with monovalent and divalent metal cations, DFT, fungicidal activity of colchicine complexes, spectroscopic studies (ESI MS, MALDI MS, NMR, FT IR)

\section{INTRODUCTION}

Colchicine 1 (Fig.1.) is a tropolone alkaloid of Colchicum autumnale. It shows antimitotic, antifibriotic, anti-inflammatory activity [1] and can efficiently exacerbate the symptoms during an attack of gout when applied in the early phase. More recently it has been introduced in the treatment of familiar Mediterranean fever [2]. Moreover, colchicine $\mathbf{1}$ is a potent anti-mitotic agent and shows carcinogenic activity [4-6]. Similarly to other alkaloids, colchicine $\mathbf{1}$ can act through blocking or activating of specific receptors or ion channels in living organisms. Its activity depends on the ability of formation of noncovalent complexes with macromolecules such as tubulin in microtubules.

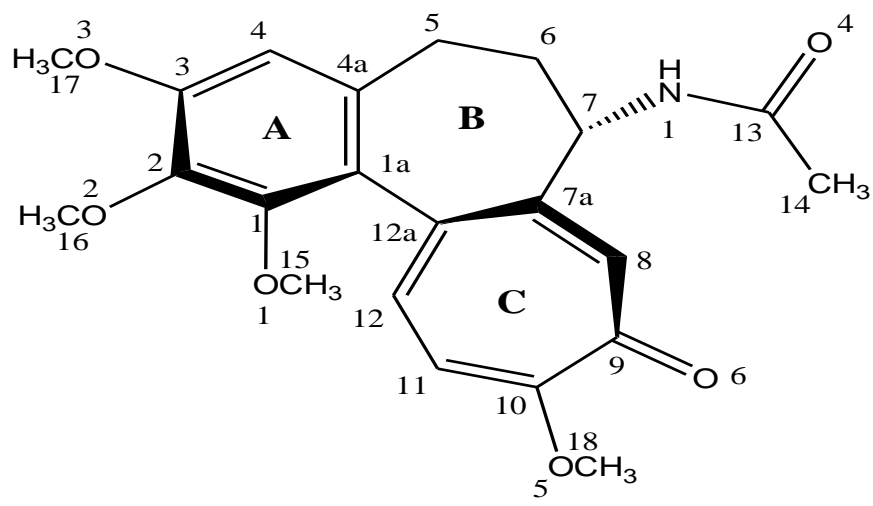

Fig. 1. Colchicine molecule, carbon and oxygen atoms numbering

In human body fluid (extracellular fluid, transcellular fluid, blood, cytosol and saliva) some electrolytes are present, in particular sodium, potassium, magnesium and calcium cations. Electrolytes like $\mathrm{Na}^{+}, \mathrm{Ca}^{2+}, \mathrm{Mg}^{2+}$ 
and anions $\mathrm{Cl}, \mathrm{HCO}_{3}{ }^{2-}, \mathrm{SO}_{4}{ }^{2-}, \mathrm{H}_{2} \mathrm{PO}_{4}{ }^{-}, \mathrm{HPO}_{4}{ }^{2-}$, play a vital role in intravascular osmotic effect that keeps electrolytes in balanced form and protects the body from infection and other blood disorders. [7-13] In order to maintain osmotic balance, the compartments of a mammal's body must be able to excrete and absorb water to and from the environment. Exchange of respective ions cause the osmotic system in the body. The ions cooperate in keeping constant $\mathrm{pH}$ of the environment because some of them are components of buffers. Inorganic ions must also be exchanged between extracellular fluid and the external environment to maintain homeostasis. It has been established that the rate of binding of colchicine to tubulin is enhanced by certain anions. Among the inorganic anions tested, only sulphate was effective. [14] In contrast to extracellular fluid, cytosol has a high concentration of potassium ions and a low concentration of sodium ions.[11] This difference in ion concentrations is critical for osmoregulation, since if the ion levels were the same inside and outside of the cell, water would enter constantly by osmosis - since the concentrations of macromolecules inside the cells are higher than their levels outside. The loss of sodium and chloride ions compensates for the osmotic effect of the higher concentration of organic molecules inside the cell. [8-14]

Not much research has been made on the formation of complexes between colchicines and cations. Only Mackay et al. in 1998 obtained a derivative of colchicine -hydrated crystals of copper(II) colchiceine (10hydroxycolchicine) that belongs to the tetragonal space group [15].

In the previous work we reported results of a study on coordination process of colchicine $\mathbf{1}$ with iodides and perchlorates of monovalent metal ions (lithium, sodium and potassium salts) [16]. Some theoretical study has been made on coordination process of colchicine - $\mathrm{Na}^{+}$cation.[17] Other biologically active compounds like: lasalocid polyoxalkyl esters [18, 19], derivatives of gossypol [20] or oligomycin A [21, 22] also were investigated as ligands in complexation process with monovalent metal ions $\mathrm{Li}^{+}, \mathrm{Na}^{+}$and $\mathrm{K}^{+}, \mathrm{Cs}^{+}$or $\mathrm{Rb}^{+}$.

To the best of our knowledge, the process of complexation of colchicine $\mathbf{1}$ with monovalent and divalent metal ions present in human body fluid such as: $\mathrm{Mg}^{2+}, \mathrm{Ca}^{2+}, \mathrm{Na}^{+}$and $\mathrm{K}^{+}$with respective anions: sulphate and carbonate has not been studied yet. This fact has prompted us to obtain and examine the structure of colchicine complexes 2-7 with water soluble sulphates and carbonates with monovalent cations: $\mathrm{Na}^{+}$and $\mathrm{K}^{+}$ and divalent cations: $\mathrm{Mg}^{2+}$ and $\mathrm{Ca}^{2+}$.

The aim of this study was the synthesis of colchicine coordinative compound with inorganic salts: carbonates and sulphates (sodium, potassium, magnesium and calcium) which show good water solubility. This study is a continuation of research work on the coordination process of colchicine and monovalent metal cations that could also play a biologically important role. New derivatives 2-7 were characterized by MS (ESI and MALDI), FT IR, ${ }^{1} \mathrm{H}$ NMR and ${ }^{13} \mathrm{C}$ NMR and subjected to theoretical studies.

Moreover, to the best of our knowledge, these compounds are for the first time in our study tested towards the fungistatic activity of the microfungi species (Aspergillus niger van Tiegen, A. versicolor, Paecilomyces variotii, Penicillium funiculosum) using the method of bioautography on thin-layer plates.[23] Some complexes were selected from among the new derivatives and tested against brown-rot fungi Coniophora puteana and Poria placenta and also against white-rot fungus Coriolus versicolor using agar and broth dilution method to determine the minimal inhibitory concentration (MIC). Colchicine itself has been tested against $A$. niger previously and it did not show fungistatic properties against this fungus.

The structures of colchicine complexes 2-7 with salts of divalent $\left(\mathrm{Mg}^{2+}, \mathrm{Ca}^{2+}\right)$ and monovalent $\left(\mathrm{Na}^{+}\right.$ and $\mathrm{K}^{+}$) metal cations are discussed. The above-mentioned ions as well as sulphate and carbonate anions are present in the human body fluids. On the basis of experiments performed and the analysis of FT IR, ${ }^{1} \mathrm{H}$ NMR, ${ }^{13} \mathrm{C}$ NMR, ESI MS and MALDI MS spectra as well as the elementary analysis and theoretical studies of these compounds, colchicine was demonstrated to have complexing capacity of the ions mentioned.

\section{MATERIAL AND METHODS}

2.1. MaterialsColchicine $\mathbf{1}$ is commercially available on ApplyChem. For complexation reaction a natural isomer (-)-(aR, 7S) of colchicine was used. Salts $\mathrm{Na}_{2} \mathrm{CO}_{3}, \mathrm{Na}_{2} \mathrm{SO}_{4}, \mathrm{~K}_{2} \mathrm{SO}_{4}, \mathrm{~K}_{2} \mathrm{CO}_{3}, \mathrm{MgSO}_{4}$ and $\mathrm{CaSO}_{4}$ from Sigma-Aldrich were obtained commercially and used without any purification. Solvents used for the synthesis were purified by standard methods.

2.2. Measurements

The NMR spectra of colchicine and its 1:1 complexes $\left(0.07 \mathrm{~mol} \mathrm{~L}^{-1}\right)$ with monovalent and divalent metal cations salts were recorded in $\mathrm{CD}_{3} \mathrm{CN}$ solutions using a Varian Gemini $300 \mathrm{MHz}$ spectrometer. All spectra were locked to deuterium resonance of $\mathrm{CD}_{3} \mathrm{CN}$. The ${ }^{1} \mathrm{H} \mathrm{NMR}$ measurements in $\mathrm{CD}_{3} \mathrm{CN}$ were carried out at the operating frequency $300.075 \mathrm{MHz}$; flip angle, $\mathrm{pw}=45^{\circ}$; spectral width, $\mathrm{sw}=4500 \mathrm{~Hz}$; acquisition time, at $=2.0 \mathrm{~s}$; relaxation delay, $\mathrm{d}_{1}=1.0 \mathrm{~s} ; \mathrm{T}=293.0 \mathrm{~K}$ and using TMS as the internal standard. No window function or zero filling was used. Digital resolution was $0.2 \mathrm{~Hz}$ per point. The error of chemical shift value was $0.01 \mathrm{ppm}$. ${ }^{13} \mathrm{C}$ NMR spectra were recorded at the operating frequency $75.454 \mathrm{MHz} ; \mathrm{pw}=60^{\circ}$; $\mathrm{sw}=19000 \mathrm{~Hz}$; at $=1.8 \mathrm{~s}$; $\mathrm{d}_{1}=1.0 \mathrm{~s} ; \mathrm{T}=293.0 \mathrm{~K}$ and TMS as the internal standard. Line broadening parameters were $0.5 \mathrm{or} 1 \mathrm{~Hz}$. The error 
of chemical shift value was $0.01 \mathrm{ppm}$. The ${ }^{1} \mathrm{H}$ and ${ }^{13} \mathrm{C}$ NMR signals were assigned for each species using one or two-dimensional spectra. The FT IR spectra of colchicine and its $1: 1$ complex $\left(0.07 \mathrm{~mol} \mathrm{dm}^{-3}\right)$ were recorded in the mid infrared region in $\mathrm{KBr}$ pellets using a Bruker IFS $113 \mathrm{v}$ spectrometer. A cell with Si windows and wedge-shaped layers was used to avoid interferences (mean layer thickness $170 \mu \mathrm{m}$ ). The spectra were taken with an IFS 113v FT-IR spectrophotometer (Bruker, Karlsruhe) equipped with a DTGS detector; resolution 2 $\mathrm{cm}^{-1}$, NSS $=125$. The Happ-Genzel apodization function was used. All manipulations with the substances were performed in a carefully dried and $\mathrm{CO}_{2}$-free glove box. The UV-Vis spectra were recorded in methanol by means of JASCO V-550 spectrophotometer at 200-600 nm of measurement range. The ESI (Electrospray Ionisation) mass spectra were recorded on a Waters/Micromass (Manchester, UK) ZQ mass spectrometer equipped with a Harvard Apparatus syringe pump. All samples were prepared in $\mathrm{CD}_{3} \mathrm{CN}$. The measurements were performed for the samples being the solutions of colchicine complexes: colchicine concentration $\left(5 \times 10^{-}\right.$ $\left.{ }^{5} \mathrm{~mol} \mathrm{dm}{ }^{-3}\right)$ with: each of the cations $\mathrm{Na}^{+}, \mathrm{K}^{+}, \mathrm{Ca}^{2+}$ and $\mathrm{Mg}^{2+}\left(2.5 \times 10^{-4} \mathrm{~mol} \mathrm{dm}^{-3}\right)$ were recorded separately. The samples were infused into the ESI source using a Harvard pump at a flow rate of $20 \mu \mathrm{min}^{-1}$. The ESI source potentials were: capillary $3 \mathrm{kV}$, lens $0.5 \mathrm{kV}$, extractor $4 \mathrm{~V}$. The standard ESI mass spectra were recorded at $30 \mathrm{~V}$. The source temperature was $120^{\circ} \mathrm{C}$ and the desolvation temperature was $300^{\circ} \mathrm{C}$. Nitrogen was used as the nebulizing and desolvation gas at flow-rates of 100 and $300 \mathrm{dm} 3 \mathrm{~h}-1$, respectively. Mass spectra were acquired in the positive ion detection mode with unit mass resolution at a step of $1 \mathrm{~m} / \mathrm{z}$ unit. The mass range for ESI experiments was from $\mathrm{m} / \mathrm{z}=100$ to $\mathrm{m} / \mathrm{z}=1400$. The elementary analysis of colchicine complexes 2-7 were carried out on Vario ELIII (Elementar, Germany).

The matrix-assisted laser desorption/ionization measurements, including MS/MS experiments, were accomplished on Waters Q-TOF Premier instrument, equipped with nitrogen laser MALDI source and MassLynx ${ }^{\mathrm{TM}}$ software. MALDI measurements were performed in the positive ion mode. In order to prepare the target spots, the methanolic solution containing matrix $\left(1 \mu \mathrm{l}\right.$, concentration $\left.0.5 \mathrm{~mol} / \mathrm{dm}^{3}\right)$ was deposited on the spot and allowed to dry at room temperature. After a few minutes $1 \mu$ of solution containing respective colchicine complexes (the concentration about $1 \mathrm{mmol} / \mathrm{dm}^{3}$ ) was placed as a next layer over the dried matrix and left to cocrystallize. The MS/MS experiment with dithranol as a matrix and argon as colliding neutral gas (at flow rate of $0.5 \mathrm{~mL} / \mathrm{min}$ ) was performed and the collision-induced fragmentation of protonated molecules $[\mathrm{M}+\mathrm{H}]^{+}$was analyzed, depending on collision energy CE (Table 2). The product ion MS/MS spectra were collected at five collision energy values, i. e. 20, 30, 40, 50 and $60 \mathrm{eV}$. It should be noticed the nanospray MS of colchicine and $\mathrm{MS}^{2}$ of the $\mathrm{m} / \mathrm{z} 400 \pm 0.5$ ion $[\mathrm{M}+\mathrm{H}]^{+}$have already been reported and representative fragment ions, which originate from $\mathrm{m} / \mathrm{z} 400$, are given, i.e. $\mathrm{m} / \mathrm{z} 382,368,358,341,326,310,298$ and 282 . The same $\mathrm{m} / \mathrm{z}$ values appear in collisionally induced dissociation as well as in previously published papers.[24-26]

\subsection{Preparation of complexes}

Complexes of colchicine 2-7 were obtained by dissolving of the respective salts and colchicine in the $1: 1$ ratio in methanol. Complexes were prepared from colchicine $(96 \mathrm{mg}, 0,25 \mathrm{mM})$ and sodium carbonate (27 $\mathrm{mg}, 0,25 \mathrm{mM})$, potassium carbonate $(35 \mathrm{mg}, 0,25 \mathrm{mM})$, sodium sulfate $(36 \mathrm{mg}, 0,25 \mathrm{mM})$, potassium sulfate (44 $\mathrm{mg}, 0,25 \mathrm{mM})$, magnesium sulfate $(30 \mathrm{mg}, 0,25 \mathrm{mM})$, calcium sulfate $(34 \mathrm{mg}, 0,25 \mathrm{mM})$, respectively. The solution was evaporated until the product started to precipitate. The resulting precipitate was filtered off and recrystallized from ethanol. The purity of all the complexes was checked by TLC. Carbon atom numbering of colchicine 1 is shown in Fig. 1.

For complex $\left[\mathrm{Na}_{2}\left(\mathrm{C}_{22} \mathrm{H}_{25} \mathrm{NO}_{6}\right) \mathrm{CO}_{3}\right]$ 2: Yield $93 \%, 117 \mathrm{mg}$; M. p. = 105-107 ${ }^{\circ} \mathrm{C}$, Anal. Calc. $49.32 \mathrm{C}$; $5.54 \mathrm{H} ; 2.50 \mathrm{~N}$ Found $48.84 \mathrm{C} ; 6.04 \mathrm{H} ; 2.53 \mathrm{~N} \mathrm{C}_{23} \mathrm{H}_{25} \mathrm{NO}_{9} \mathrm{Na}_{2} \cdot 3 \mathrm{H}_{2} \mathrm{O}$. UV vis $\left(\mathrm{CH}_{3} \mathrm{OH}\right) \lambda_{\max }[\mathrm{nm}] 351,244,{ }^{1} \mathrm{H}$ NMR (300 MHz, CD 3 CN, TMS, ppm, $\left.25^{\circ} \mathrm{C}\right): 6.69$ (HC-4, s), 2.33, $2.55\left(\mathrm{H}_{2} \mathrm{C}-5\right), 1.83,2.11\left(\mathrm{H}_{2} \mathrm{C}-6\right), 4.37$ (HC7), $7.24(\mathrm{HC}-8, \mathrm{~s}), 6.94(\mathrm{HC}-11, \mathrm{~d}, J=10.7 \mathrm{~Hz}), 7.17(\mathrm{HC}-12, \mathrm{~d}, J=10.7 \mathrm{~Hz}), 3.61\left(\mathrm{H}_{3} \mathrm{C}-15, \mathrm{~s}\right), 3.86\left(\mathrm{H}_{3} \mathrm{C}-16\right.$, s), $3.83\left(\mathrm{H}_{3} \mathrm{C}-17, \mathrm{~s}\right), 3.91\left(\mathrm{H}_{3} \mathrm{C}-18, \mathrm{~s}\right), 1.88\left(\mathrm{H}_{3} \mathrm{C}-14, \mathrm{~s}\right), 7.36(\mathrm{NH}, \mathrm{d}, J=7.00 \mathrm{~Hz}) ;{ }^{13} \mathrm{C} \mathrm{NMR}\left(75 \mathrm{MHz}, \mathrm{CD}_{3} \mathrm{CN}\right.$, TMS, ppm): 151.72 (C-1), 126.57 (C-1a), 142.14 (C-2), 154.44 (C-3), 108.57 (C-4), 136.74 (C-4a), 30.27 (C5), 36.86 (C-6), 52.99 (C-7), 152.05 (C-7a), 131.37 (C-8), 179.63 (C-9), 164.89 (C-10), 113.09 (C-11), 136.74 (C-12), 135.59 (C-12a), 61.65 (C-15), 61.42 (C-16), 56.62 (C-17), 56.80 (C-18), 170.26 (C-13), 22.72 (C-14). IR (KBr): 3403, 3273, 2936, 2838, 1662 (vC=O), 1615 (vC=O), 1589, 1558, 1487, 1431, 1284, 1253, 1138 , $1093,841\left(\mathrm{CO}_{3}{ }^{2-}\right)$.

For complex $\left[\mathrm{K}_{2}\left(\mathrm{C}_{22} \mathrm{H}_{25} \mathrm{NO}_{6}\right) \mathrm{CO}_{3}\right]$ 3: Yield 96\%, $129 \mathrm{mg}$; M. p. = 182-184 ${ }^{\circ} \mathrm{C}$, Anal. Calc. for $\mathrm{C}_{22} \mathrm{H}_{25} \mathrm{NO}_{6} \cdot \mathrm{K}_{2} \mathrm{CO}_{3} \cdot 0.5 \mathrm{H}_{2} \mathrm{O} 50.55 \mathrm{C} ; 4.56 \mathrm{H} ; 2.56 \mathrm{~N} \%$, Found $49.68 \mathrm{C} ; 4.16 \mathrm{H} ; 2.41 \mathrm{~N}$. UV vis $\left(\mathrm{CH}_{3} \mathrm{OH}\right) \lambda_{\max }$ [nm] 352, 244; ${ }^{1} \mathrm{H}$ NMR (300 MHz, $\left.\mathrm{CD}_{3} \mathrm{CN}, \mathrm{TMS}, \mathrm{ppm}, 25^{\circ} \mathrm{C}\right): 6.72(\mathrm{HC}-4, \mathrm{~s}), 2.26,2.55\left(\mathrm{H}_{2} \mathrm{C}-5\right), 1.90,2.26$ $\left(\mathrm{H}_{2} \mathrm{C}-6\right), 4.37$ (HC-7), 7.18 (HC-8, s), 6.93 (HC-11, d, J = 10.7 Hz), 7.18 (HC-12, d, J = 10.6 Hz), $3.61\left(\mathrm{H}_{3} \mathrm{C}-15\right.$, s), $3.86\left(\mathrm{H}_{3} \mathrm{C}-16, \mathrm{~s}\right), 3.86\left(\mathrm{H}_{3} \mathrm{C}-17, \mathrm{~s}\right), 3.95\left(\mathrm{H}_{3} \mathrm{C}-18, \mathrm{~s}\right), 1.90\left(\mathrm{H}_{3} \mathrm{C}-14, \mathrm{~s}\right), 7.36(\mathrm{NH}, \mathrm{d}, J=7.00 \mathrm{~Hz}) ;{ }^{13} \mathrm{C} \mathrm{NMR}$ (75 MHz, CD $\left.{ }_{3} \mathrm{CN}, \mathrm{TMS}, \mathrm{ppm}\right): 151.73$ (C-1), 126.59 (C-1a), 142.15 (C-2), 154.43 (C-3), 108.56 (C-4), 136.68 (C-4a), 30.29 (C-5), 36.86 (C-6), 52.97 (C-7), 151.99 (C-7a), 131.36 (C-8), 179.66 (C-9), 164.88 (C-10), 112.99 (C-11), 136.68 (C-12), 135.59 (C-12a), 61.63 (C-15), 61.41 (C-16), 56.61 (C-17), 56.79 (C-18), 170.12 (C-13), 
22.76 (C-14). IR (KBr): 3421, 3272, 2936, 1658 (vC=O), 1616 (vC=O), 1589, 1559, 1487, 1285, 1253, 1139 , $1093,832\left(\mathrm{CO}_{3}{ }^{2-}\right)$.

For complex $\left[\mathrm{Na}_{2}\left(\mathrm{C}_{22} \mathrm{H}_{25} \mathrm{NO}_{6}\right) \mathrm{SO}_{4}\right]$ 4: Yield 94\%, $127 \mathrm{mg}$; M. p. = 150-153 ${ }^{\circ} \mathrm{C}$, Anal. Calc. for $\mathrm{C}_{22} \mathrm{H}_{25} \mathrm{NO}_{6} \cdot \mathrm{Na}_{2} \mathrm{SO}_{4} \cdot 0.5 \mathrm{H}_{2} \mathrm{O} 48.00 \mathrm{C} ; 4.72 \mathrm{H} ; 2.56 \mathrm{~N}$, Found $48.16 \mathrm{C} ; 5.16 \mathrm{H} ; 2.44 \mathrm{~N} \%$. UV vis $\left(\mathrm{CH}_{3} \mathrm{OH}\right) \lambda_{\max }$ [nm] 351, 242; ${ }^{1} \mathrm{H}$ NMR (300 MHz, $\mathrm{CD}_{3} \mathrm{CN}$, TMS, ppm, $\left.25^{\circ} \mathrm{C}\right): 6.69$ (HC-4, s), 2.34, $2.55\left(\mathrm{H}_{2} \mathrm{C}-5\right), 1.83,2.12$ $\left(\mathrm{H}_{2} \mathrm{C}-6\right), 4.37$ (HC-7), 7.23 (HC-8, s), 6.94 (HC-11, d, J=11.2 Hz), 7.16 (HC-12, d, J = 10.7 Hz), $3.61\left(\mathrm{H}_{3} \mathrm{C}-15\right.$, s), $3.86\left(\mathrm{H}_{3} \mathrm{C}-16, \mathrm{~s}\right), 3.83\left(\mathrm{H}_{3} \mathrm{C}-17, \mathrm{~s}\right), 3.91\left(\mathrm{H}_{3} \mathrm{C}-18, \mathrm{~s}\right), 1.88\left(\mathrm{H}_{3} \mathrm{C}-14, \mathrm{~s}\right), 7.35(\mathrm{NH}, \mathrm{d}, J=7.00 \mathrm{~Hz}) ;{ }^{13} \mathrm{C} \mathrm{NMR}$ (75 MHz, CD ${ }_{3} \mathrm{CN}$, TMS, ppm): 151.72 (C-1), 126.57 (C-1a), 142.13 (C-2), 154.43 (C-3), 108.57 (C-4), 136.74 (C-4a), 30.27 (C-5), 36.85 (C-6), 52.99 (C-7), 152.05 (C-7a), 131.34 (C-8), 179.70 (C-9), 164.87 (C-10), 113.08 (C-11), 136.74 (C-12), 135.62 (C-12a), 61.65 (C-15), 61.42 (C-16), 56.61 (C-17), 56.81 (C-18), 170.26 (C-13), 22.76 (C-14). IR (KBr): 3410, 3271, 2964, 2936, 1661 (vC=O), 1614 (vC=O), 1589, 1556, 1487, 1284, 1253, $1137,1094$.

For complex $\left[\mathrm{K}_{2}\left(\mathrm{C}_{22} \mathrm{H}_{25} \mathrm{NO}_{6}\right) \mathrm{SO}_{4}\right]$ 5: Yield 95\%, $136 \mathrm{mg}$; M. p. = 153-155 ${ }^{\circ} \mathrm{C}$, Anal. Calc. for $\mathrm{C}_{22} \mathrm{H}_{25} \mathrm{NO}_{6} \cdot \mathrm{K}_{2} \mathrm{SO}_{4} \cdot 0.5 \mathrm{H}_{2} \mathrm{O} 48.53 \mathrm{C} ; 4.78 \mathrm{H} ; 2.57 \mathrm{~N}$, Found $48.51 \mathrm{C} ; 4.00 \mathrm{H} ; 2.44 \mathrm{~N} \%$. UV vis $\left(\mathrm{CH}_{3} \mathrm{OH}\right) \lambda_{\max }$ [nm] 351, 243; ${ }^{1} \mathrm{H}$ NMR (300 MHz, $\mathrm{CD}_{3} \mathrm{CN}, \mathrm{TMS}$, ppm, 25 $\left.{ }^{\circ} \mathrm{C}\right): 6.96$ (HC-4, s), 2.24, $2.56\left(\mathrm{H}_{2} \mathrm{C}-5\right), 1.81,2.12$ $\left(\mathrm{H}_{2} \mathrm{C}-6\right), 4.36$ (HC-7), 7.18 (HC-8, s), 6.92 (HC-11, d, J = 11.2 Hz), 7.16 (HC-12, d, J = 10.7 Hz), $3.61\left(\mathrm{H}_{3} \mathrm{C}-15\right.$, s), $3.86\left(\mathrm{H}_{3} \mathrm{C}-16, \mathrm{~s}\right), 3.83\left(\mathrm{H}_{3} \mathrm{C}-17, \mathrm{~s}\right), 3.90\left(\mathrm{H}_{3} \mathrm{C}-18, \mathrm{~s}\right), 1.88\left(\mathrm{H}_{3} \mathrm{C}-14, \mathrm{~s}\right), 7.21(\mathrm{NH}, \mathrm{d}, J=7.00 \mathrm{~Hz}) ;{ }^{13} \mathrm{C} \mathrm{NMR}$ (75 MHz, CD ${ }_{3} \mathrm{CN}$, TMS, ppm): 151.74 (C-1), 126.60 (C-1a), 142.14 (C-2), 154.42 (C-3), 108.56 (C-4), 136.63 (C-4a), 30.28 (C-5), 36.85 (C-6), 52.95 (C-7), 151.88 (C-7a), 131.35 (C-8), 179.64 (C-9), 164.87 (C-10), 113.93 (C-11), 136.63 (C-12), 135.59 (C-12a), 61.63 (C-15), 61.41 (C-16), 56.60 (C-17), 56.78 (C-18), 170.12 (C-13), 22.74 (C-14), IR (KBr): 3433, 3275, 2936, 1663 (vC=O), 1615 (vC=O), 1589, 1558, 1487, 1284, 1252, 1138, 1093.

For complex $\left[\mathrm{Mg}\left(\mathrm{C}_{22} \mathrm{H}_{25} \mathrm{NO}_{6}\right) \mathrm{SO}_{4}\right]$ 6: Yield 93\%, $121 \mathrm{mg} ; \mathrm{M}$. p. $=110-112^{\circ} \mathrm{C}$, Anal. Calc. for $\mathrm{C}_{22} \mathrm{H}_{25} \mathrm{NO}_{6} \cdot \mathrm{MgSO}_{4} \cdot \mathrm{H}_{2} \mathrm{O} 49.16 \mathrm{C} ; 5.03 \mathrm{H} ; 2.61 \mathrm{~N}$, Found $56.61 \mathrm{C} ; 6.64 \mathrm{H} ; 2.96 \mathrm{~N} \%$ ]. UV vis $\left(\mathrm{CH}{ }_{3} \mathrm{OH}\right) \lambda_{\max }$ [nm] 351, 244; ${ }^{1} \mathrm{H}$ NMR (300 MHz, $\mathrm{CD}_{3} \mathrm{CN}, \mathrm{TMS}$, ppm, 25 $\left.{ }^{\circ} \mathrm{C}\right): 6.96$ (HC-4, s), 2.19, $2.56\left(\mathrm{H}_{2} \mathrm{C}-5\right), 1.80,2.10$ $\left(\mathrm{H}_{2} \mathrm{C}-6\right), 4.36$ (HC-7), 7.16 (HC-8, s), 6.91 (HC-11, d, $\left.J=10.6 \mathrm{~Hz}\right), 7.11(\mathrm{HC}-12, \mathrm{~d}, J=10.7 \mathrm{~Hz}), 3.60\left(\mathrm{H}_{3} \mathrm{C}-15\right.$, s), $3.86\left(\mathrm{H}_{3} \mathrm{C}-16, \mathrm{~s}\right), 3.83\left(\mathrm{H}_{3} \mathrm{C}-17, \mathrm{~s}\right), 3.90\left(\mathrm{H}_{3} \mathrm{C}-18, \mathrm{~s}\right), 1.88\left(\mathrm{H}_{3} \mathrm{C}-14, \mathrm{~s}\right), 7.19(\mathrm{NH}, \mathrm{d}, J=7.00 \mathrm{~Hz}) ;{ }^{13} \mathrm{C} \mathrm{NMR}$ (75 MHz, $\left.\mathrm{CD}_{3} \mathrm{CN}, \mathrm{TMS}, \mathrm{ppm}\right): 151.77$ (C-1), 126.64 (C-1a), 142.19 (C-2), 154.43 (C-3), 108.58 (C-4), 136.58 (C-4a), 30.30 (C-5), 36.89 (C-6), 52.94 (C-7), 151.77 (C-7a), 131.37 (C-8), 179.61 (C-9), 164.88 (C-10), 112.85 (C-11), 136.58 (C-12), 135.59 (C-12a), 61.62 (C-15), 61.41 (C-16), 56.62 (C-17), 56.77 (C-18), 170.03 (C-13), 22.76 (C-14), IR (KBr): 3403, 3269, 2935, 1662 (vC=O), 1615 (vC=O), 1589, 1557, 1487, 1287, 1252, 1137 , 1093.

For complex $\left[\mathrm{Ca}\left(\mathrm{C}_{22} \mathrm{H}_{25} \mathrm{NO}_{6}\right) \mathrm{SO}_{4}\right]$ 7: Yield 94\%, $126 \mathrm{mg}$; M. p. = 157-159 ${ }^{\circ} \mathrm{C}$, Anal. Calc. for $\mathrm{C}_{22} \mathrm{H}_{25} \mathrm{NO}_{6} \cdot \mathrm{CaSO}_{4} \cdot \mathrm{H}_{2} \mathrm{O} 45.36 \mathrm{C} ; 4.46 \mathrm{H} ; 2.40 \mathrm{~N}$ Found $56.44 \mathrm{C} ; 6.28 \mathrm{H} ; 2.90 \mathrm{~N} \%$. UV vis $\left(\mathrm{CH}_{3} \mathrm{OH}\right) \lambda_{\max }[\mathrm{nm}]$ 351, 244; ${ }^{1} \mathrm{H}$ NMR $\left(300 \mathrm{MHz}, \mathrm{CD}_{3} \mathrm{CN}\right.$, TMS, ppm, $\left.25^{\circ} \mathrm{C}\right): 6.69$ (HC-4, s), 2.33, $2.56\left(\mathrm{H}_{2} \mathrm{C}-5\right), 1.81,2.11\left(\mathrm{H}_{2} \mathrm{C}-\right.$ 6), 4.36 (HC-7), 7.15 (HC-8, s), 6.91 (HC-11, d, $J=10.7 \mathrm{~Hz}), 7.15(\mathrm{HC}-12, \mathrm{~d}, J=10.7 \mathrm{~Hz}), 3.61\left(\mathrm{H}_{3} \mathrm{C}-15, \mathrm{~s}\right)$, $3.86\left(\mathrm{H}_{3} \mathrm{C}-16, \mathrm{~s}\right), 3.83\left(\mathrm{H}_{3} \mathrm{C}-17, \mathrm{~s}\right), 3.90\left(\mathrm{H}_{3} \mathrm{C}-18, \mathrm{~s}\right), 1.88\left(\mathrm{H}_{3} \mathrm{C}-14, \mathrm{~s}\right), 7.29(\mathrm{NH}, \mathrm{d}, J=7.00 \mathrm{~Hz}) ;{ }^{13} \mathrm{C}$ NMR $(75$ $\left.\mathrm{MHz}, \mathrm{CD}_{3} \mathrm{CN}, \mathrm{TMS}, \mathrm{ppm}\right): 151.81$ (C-1), 126.64 (C-1a), 142.18 (C-2), 154.43 (C-3), 108.59 (C-4), 136.60 (C4a), 30.30 (C-5), 36.89 (C-6), 52.95 (C-7), 151.81 (C-7a), 131.37 (C-8), 179.63 (C-9), 164.89 (C-10), 112.88 (C-11), 135.60 (C-12), 135.47 (C-12a), 61.62 (C-15), 61.42 (C-16), 56.62 (C-17), 56.78 (C-18), 170.05 (C-13), 22.76 (C-14), IR (KBr): 3433, 3274, 2934, 2838, 1663 (vC=O), 1615 (vC=O), 1589, 1558, 1487, 1284, 1253, $1139,1093$.

2.4. Quantum-mechanical calculations

All calculations were performed, within DFT framework at M06/SDD level of theory [27-28], selected on the basis of the results from extensive comparative studies of Zhao and Truhlar [27], recommended for calculations for compounds containing metal atoms [28-30]. Partial atomic charges were calculated at the same level of theory. Apart from the most popular Mulliken [31] derived point charges, Bader method based on partitioning of electron density distribution, Born [32] or Szigeti [33] effective charges based on charges derived from dipole-dependent properties and CHELPG [34] method based on electrostatic potential were considered. Nevertheless, for the sake of conciseness of the manuscript we selected the method of Mulliken point charges. Counterpoise correction [35, 36] was calculated to access Basis Set Superposition Error (BSSE). All calculations were performed with the GAUSSIAN 09 [37].

\subsection{Fungicidal activity}

Fungi strains. The antifungal activity of tested compounds was evaluated against microfungi causing mould growth phenomenon Aspergillus niger van Tiegen BAM 4 (ATCC 6275), Aspergillus versicolor BAM 8 (ATCC 11730), Paecilomyces variotii BAM 19 (ATCC 18502), Penicillium funiculosum BAM 22 (ATCC 11797 ) and against brown-rot fungi belonging to the phylum Basidiomycota (Coniophora puteana (Schumach). 
P. Karst. BAM Ebw. 15, Poria placenta (Fries) Cook sensu J. Eriksson (FPRL 280) and also white-rot fungus Coriolus versicolor (Linnaeus) Quélet (CTB 863A).

Bioautography on thin-layer plates. The complexes of colchicine $(10 \mathrm{mg})$ to be tested were dissolved in $200 \mu \mathrm{L}$ methanol to obtain a high concentration of the solution. Portions of $10 \mu \mathrm{L}$ volumes of tested solutions were applied as small spots on TLC plates $\left(2 \mathrm{x} 4 \mathrm{~cm}\right.$ silica gel $60 \mathrm{~F}_{254}$ sheets, Merck) using micropipette. The organic solvent was evaporated by a stream of air. TLC plates with added solutions were placed in a Petri dish on the agar medium and then coated with agar medium with concentration of spores suspension in concentration of $10^{6} \mathrm{CFU} / \mathrm{mL}$, which corresponds to the logarithmic growth phase. The fungal spores were obtained from twoweek agar slants. The layers were incubated for 7 days in a moist chamber with relative humidity (RH) above $95 \%$ at $28^{\circ} \mathrm{C}$ in the dark and the appearance of blank zones in the mycelium layer indicated antifungal activity. Fungal growth was evaluated macroscopically throughout the study period. From our previous studies we concluded that 7 days is a sufficient time for estimation of the fungal activity [38]. Each experiment was performed in triplicate, the results for each compounds were compared to the control plates. Visual evaluation of moulds growth on samples was made according to the three point scale of intensity mycelium growth:

s"“- no visible growth under the microscope

, \pm “ - growth visible with the naked eye, growth of hyphae without spores

,,+" - growth visible with the naked eye, sporulation mycelium.

Agar dilution method. Complexes of colchicine $(\mathbf{3}, \mathbf{6})$ were tested against brown-rot fungi $C$. puteana and $P$. placenta and also against white-rot fungus $C$. versicolor using agar dilution methods to determine the minimal inhibitory concentration (MIC). Solutions with different chemical concentrations (from 0.0001 to $0.1 \mathrm{~g} / 100 \mathrm{~mL}$ solutions) were added into sterilized potato dextrose agar medium (PDA) prepared in Petri dishes ( $90 \mathrm{~mm}, h 10 \mathrm{~mm}$ ). Each PDA sterile plate contained $9 \mathrm{~mL}$ of PDA and $1 \mathrm{~mL}$ of an methanol solutions of complexes. For all test fungi, PDA plates without any additives were made and used as control plates. The solid plates were inoculated at the center of the Petri dish and incubated in the dark at $22^{\circ} \mathrm{C}$ and $70 \% \mathrm{RH}$. The incubation was stopped when the mycelia mass of control plates had filled the plates. The fungal growth (colony diameter) and percentage inhibition was evaluated with antifungal index (AI) calculated according to the formula AI $(\%)=[(\mathrm{A}-\mathrm{B}) / \mathrm{A}] \times 100$, where $\mathrm{A}$ and $\mathrm{B}$ represent the area covered with mycelium on plates, respectively.

\section{RESULTS}

Colchicine 1 and respective inorganic salts $\left(\mathrm{Na}_{2} \mathrm{CO}_{3}, \mathrm{~K}_{2} \mathrm{CO}_{3}, \mathrm{Na}_{2} \mathrm{SO}_{4}, \mathrm{~K}_{2} \mathrm{SO}_{4}, \mathrm{MgSO}_{4}, \mathrm{CaSO}_{4}\right)$ in a ratio 1:1 $\mathrm{M}$ were dissolved in methanol and were stirred for $24 \mathrm{~h}$ in room temperature. Compounds 2-7 were obtained as pale to dark yellow solids with very good yields. The complexes 2-7 of colchicine $\mathbf{1}$ with sodium, potassium, magnesium and calcium carbonates and sulphates were subjected to spectral studies ${ }^{13} \mathrm{C}$ NMR and ${ }^{1}$ H NMR, ESI MS, MALDI MS, UV-Vis, FT IR, fungicidal activity and theoretical studies. Some of the data obtained are given in Experimental Section.

3.1 Mass spectrometry

In order to elucidate the structures of gas-phase ions derived from the complexes obtained, we applied two mass spectral techniques - electrospray ionization mass spectrometry (ESI MS), where the analyte is introduced to the instrument as a solution in polar solvent, and MALDI mass spectrometry, where the analyte is deposited on the target in the presence of an excess of additional auxiliary compound (matrix) and desorbed from the solid state to gas phase by laser beam. The first method is regarded very mild ionization way, while the latter offers somewhat harder approach.

3.1.1. ESI MS studies

The $\mathrm{m} / \mathrm{z}$ signals in the ESI MS spectra of the complexes formed between colchicine $\mathbf{1}$ and monovalent or divalent cations $\left(\mathrm{M}=\mathrm{Na}^{+}, \mathrm{K}^{+}, \mathrm{Mg}^{2+}\right.$ and $\left.\mathrm{Ca}^{2+}\right)$ at the cone voltage of $30 \mathrm{~V}$ are given in Table 1 . while the ESI MS spectra of 1:1 (M/M) complexes of colchicine with $\mathrm{M}_{\mathrm{n}} \mathrm{X}$ salts $(\mathrm{M}=$ metal, $\mathrm{n}=1$ or $2, \mathrm{X}=$ carbonate or sulphate) and an example of ESI MS spectra of complexes $\mathbf{3}$ and $\mathbf{4}$ are shown in Fig. 2 a and b.

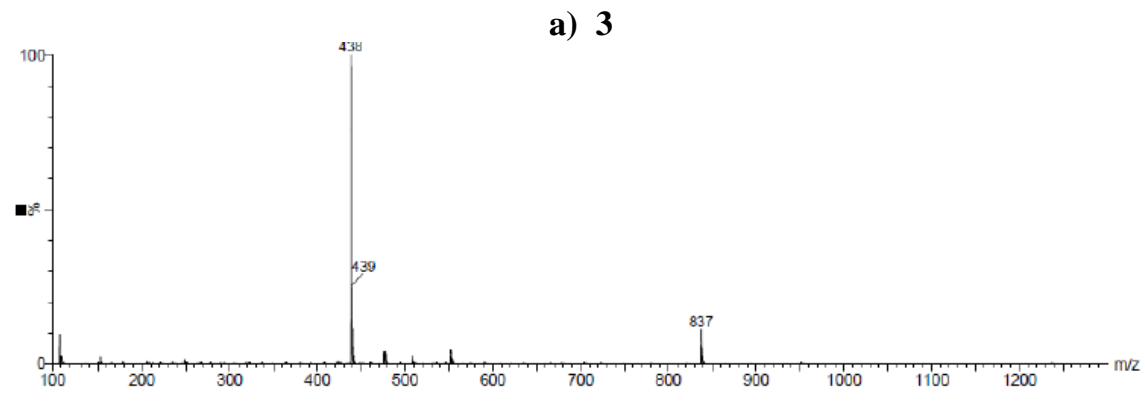

b) 4 


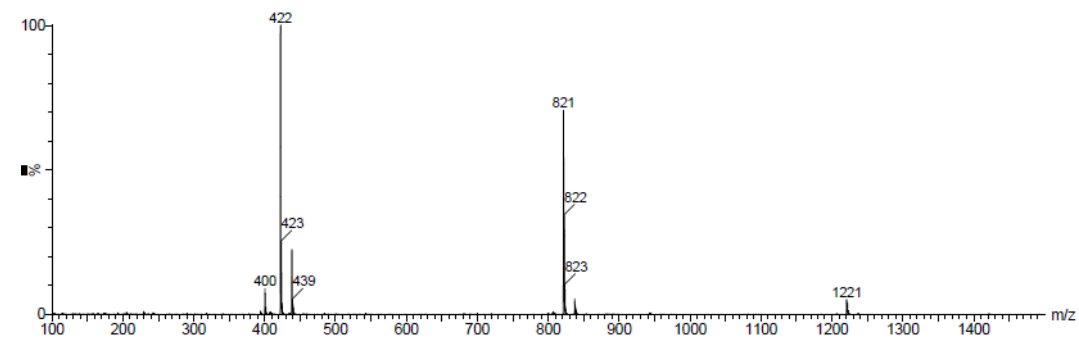

Fig. 2. The ESI MS mass spectra of colchicine complex with potassium carbonate 3 and sodium sulfate 4

General scheme for colchicine complexes 2-7 is given in Figure 3. All spectra of the colchicine complexes with $\mathrm{Na}^{+} \mathbf{2}, \mathbf{4}$ and $\mathrm{K}^{+} \mathbf{3}, \mathbf{5}$ cations show signals at $\mathrm{m} / \mathrm{z}=422$ and 438, respectively. These signals can be assigned to the respective $1: 1$ complexes.

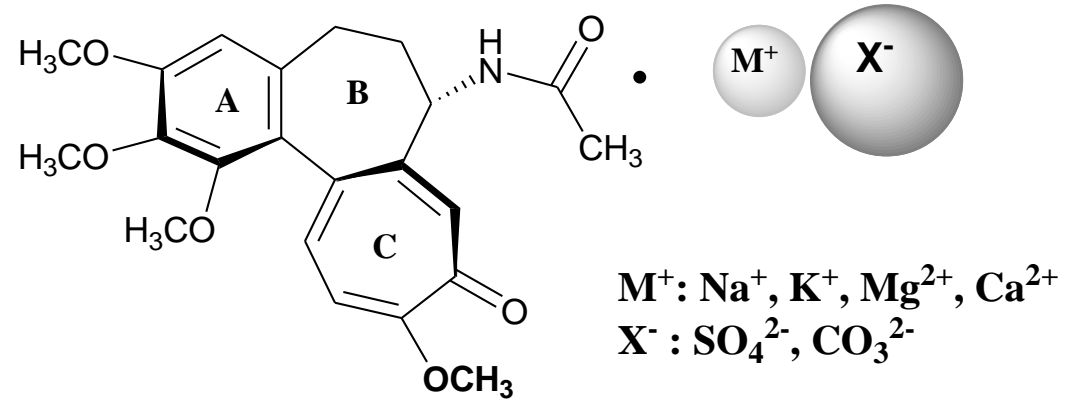

Fig. 3. General scheme for colchicine complexes 2-7

Table 1: The main peaks in the ESI MS mass spectra of the complexes 2-7 measured at cv=30V ES ${ }^{+}$

\begin{tabular}{lcccccc}
\hline & \multicolumn{5}{c}{$\mathrm{m} / \mathrm{z}$ values } \\
\cline { 2 - 6 } Mixture & Comple & Complex & Complex & Comple & Complex & Complex \\
& $1: 1$ & $1: 1$ & $2: 1$ & $3: 1$ & $2: 1$ & $2: 1$ \\
& {$[\mathbf{1}+\mathrm{M}]^{+}$} & $\begin{array}{c}\left.\mathbf{1}+\mathrm{M}^{2+}-\mathrm{H}\right]^{+} \\
{[\mathbf{1}+\mathrm{M}]^{2+}}\end{array}$ & {$[2 \cdot \mathbf{1}+\mathrm{M}]^{+}$} & {$[3 \cdot \mathbf{1}+\mathrm{M}]$} & {$[2 \mathbf{1}+\mathrm{M}]^{2+}$} & {$\left[2 \cdot \mathbf{1}+\mathrm{M}^{2+}-\mathrm{H}\right]^{+}$} \\
\hline $\mathbf{2}$ & 422 & - & 821 & - & - & - \\
$\mathbf{3}$ & 438 & - & 837 & - & - & - \\
$\mathbf{4}$ & 422 & - & 821 & 1221 & - & - \\
$\mathbf{5}$ & 438 & - & 837 & - & - & - \\
$\mathbf{6}$ & - & 422 & - & - & 411 & 821 \\
$\mathbf{7}$ & - & - & - & - & 438 & 837 \\
\hline \multicolumn{7}{c}{}
\end{tabular}

The appearance of signals at $\mathrm{m} / \mathrm{z}=821$ and 837 for $\mathrm{Na}^{+} \mathbf{2}, \mathbf{4}$ and for $\mathrm{K}^{+} \mathbf{3}, \mathbf{5}$ colchicine complexes indicates the formation of the colchicine complexes with $\mathrm{Na}^{+}$and $\mathrm{K}^{+}$cations of $2: 1$ stoichiometry, respectively. Unexpectedly, the ESI MS spectrum of colchicine complex with sodium sulphate 4 shows a signal at $\mathrm{m} / \mathrm{z}=$ 1221, which suggests 3:1 stoichiometry. In the ESI MS spectra $\mathrm{ES}^{+}$there are no signals which can be assigned to the structures in which carbonate (for complexes $\mathbf{2}$ and 3) or sulphate (for complexes 4, 5, 6 and 7) anions are involved. A comparison of the relative intensities of the respective signals shows that $\mathrm{Na}^{+}$and $\mathrm{K}^{+}$cations preferentially form 1:1 complexes.

In the ES ${ }^{-}$in ESI MS mass spectra some specific signals can be observed especially for colchicine complex with sodium sulphate 4. For all obtained complexes 2-7 a signal at $\mathrm{m} / \mathrm{z}=398$ which can be assigned to $\left[\mathrm{M}-\mathrm{H}^{+}\right]^{-}$was observed. Moreover for 4, 5 and 7, other signals were observed at $\mathrm{m} / \mathrm{z}=797$ which can be assigned to $2 \cdot \mathbf{1}-\mathrm{H}^{+}$and also for $\mathbf{4}$ and $\mathbf{5}$ a signal at $\mathrm{m} / \mathrm{z}=496$ which can be assigned to $\mathbf{1}+\mathrm{R}^{2-}+\mathrm{H}^{+}\left(\mathrm{R}=\mathrm{SO}_{4}{ }^{2-}\right)$, which indicates the coordination of one colchicine molecule with one sulphate ion and proton. For complex 4 some other much more complicated complexes were observed in negative ion mode, assigned to signal at $\mathrm{m} / \mathrm{z}=895$ and $\mathrm{m} / \mathrm{z}=917$ indicating the formation of $2: 1: 1$ stoichiometry complexes, $2 \cdot \mathbf{1}+\mathrm{R}^{2-}+\mathrm{H}^{+}$and $2 \cdot \mathbf{1}+\mathrm{R}^{2-}+\mathrm{Na}^{+}$, respectively. For colchicine complexes with carbonates $\mathbf{2}$ and $\mathbf{3}$, no signals of this type were observed. 
In the ESI MS mass spectra both $\mathrm{ES}^{+}$and $\mathrm{ES}^{-}$signals assigned to the most complicated complexes were observed for the colchicine complex with sodium sulphate 4. In the previous study on colchicine complexes with lithium, sodium and potassium perchlorates and iodides no signals in ESI MS ES have been observed [16].

\subsection{2.. MALDI studies}

Four colchicine complexes with monovalent $\mathrm{Na}^{+}$and $\mathrm{K}^{+}$cations $\mathbf{2 - 5}$ were formed and investigated by MALDI mass spectrometry. Complexes 2-5 with the salts: $\mathrm{Na}_{2} \mathrm{CO}_{3}, \mathrm{~K}_{2} \mathrm{CO}_{3}, \mathrm{Na}_{2} \mathrm{SO}_{4}$ and $\mathrm{K}_{2} \mathrm{SO}_{4}$, were tested in order to establish the cation and anion importance for complexing process. It should be noted that the nanospray MS of colchicine and $\mathrm{MS}^{2}$ of the $\mathrm{m} / \mathrm{z} 400 \pm 0.5$ ion $[1+\mathrm{H}]^{+}$have already been reported and representative fragment ions, which originate from $\mathrm{m} / \mathrm{z}$ 400, are given, i.e. $\mathrm{m} / \mathrm{z} \mathrm{382,} \mathrm{368,} \mathrm{358,} \mathrm{341,} \mathrm{326,} \mathrm{310,} 298$ and 282 . In collisionally induced dissociation MS/MS spectra of precursor ions $[\mathbf{1}+\mathrm{Na}]^{+}$and $[\mathbf{1}+\mathrm{K}]^{+}$the same $\mathrm{m} / \mathrm{z}$ values of fragment ions are often found as in previously published papers, concerning the fragmentation of colchicine pseudomolecular ion $[\mathbf{1}+\mathrm{H}]^{+}$. [24-26]

In the MALDI TOF MS spectra of colchicine and its complexes with alkali metal ions 2-5 with dithranol as a matrix: the ions $\left[1+\mathrm{Na}^{+}\right]$and $\left[1+\mathrm{K}^{+}\right]$respectively, were observed, the data (elemental composition and relative abundance) are given in Table. 2 below.

Table 2: Mass spectral data from MALDI TOF spectra (positive ion mode, matrix DIT) of colchicine

\begin{tabular}{|c|c|c|c|c|c|}
\hline $\begin{array}{c}\text { Ion } \\
\mathrm{M}=\mathrm{Na} \text { or } \mathrm{K}\end{array}$ & $\begin{array}{c}\text { elemental } \\
\text { composition }\end{array}$ & $\begin{array}{c}2 \\
m / z \\
(\% \text { r. a. })\end{array}$ & $\begin{array}{c}\mathbf{3} \\
\mathrm{m} / z \\
(\% \text { r. a. })\end{array}$ & $\begin{array}{c}4 \\
m / z \\
(\% \text { r. a. })\end{array}$ & $\begin{array}{c}\mathbf{5} \\
m / z \\
(\% \text { r. a. })\end{array}$ \\
\hline$[2 \cdot \mathbf{1}+\mathrm{M}]^{+}$ & & - & - & $821(22)$ & $837(11)$ \\
\hline$[1+\mathrm{M}]^{+}$ & $\begin{array}{l}\mathrm{C}_{22} \mathrm{H}_{25} \mathrm{NO}_{6} \mathrm{Na} / \\
\mathrm{C}_{22} \mathrm{H}_{25} \mathrm{NO}_{6} \mathrm{~K}\end{array}$ & $422(11)$ & $\begin{array}{l}422(25) \\
438(42)\end{array}$ & $422(25)$ & $\begin{array}{ll}422 & (22) \\
438 & (61)\end{array}$ \\
\hline$[1+\mathrm{H}]^{+}$ & $\mathrm{C}_{22} \mathrm{H}_{26} \mathrm{NO}_{6}$ & $400(11)$ & - & - & $400(100)$ \\
\hline$\left[1-\mathrm{H}_{2} \mathrm{NCOCH}_{3}+\mathrm{H}\right]^{+}$ & $\mathrm{C}_{20} \mathrm{H}_{21} \mathrm{O}_{5}$ & $341(44)$ & - & $341(59)$ & $341(90)$ \\
\hline & $\mathrm{C}_{18} \mathrm{H}_{18} \mathrm{O}_{3}$ & $\begin{array}{l}282(44) \\
181(53) \\
165(19) \\
152(100)\end{array}$ & $\begin{array}{l}282(17) \\
181(75) \\
166(50) \\
152(100)\end{array}$ & $\begin{array}{c}282(75) \\
181(56) \\
165(100) \\
152(81) \\
\end{array}$ & $282 \quad(2)$ \\
\hline
\end{tabular}

MALDI as an ionization technique is less soft than ESI, because due to the laser use, the fragmentation occurs in spite of the protective role of the matrix and, as a result, in the TOF $\mathrm{LD}^{+}$mass spectra of colchicine complexes with both sodium and potassium salts some fragment ions characteristic of colchicine itself are observed $\mathrm{m} / \mathrm{z}=$ $341, \mathrm{~m} / \mathrm{z}=282, \mathrm{~m} / \mathrm{z}=181, \mathrm{~m} / \mathrm{z} 165, \mathrm{~m} / \mathrm{z} 152$.

In the TOF MS LD ${ }^{+}$mass spectra of colchicine complexes with potassium salts some fragment ions characteristic of colchicine itself are observed $\mathrm{m} / \mathrm{z}=341, \mathrm{~m} / \mathrm{z}=282$, and in the TOF MS LD $\mathrm{m}^{-} / \mathrm{z}=238 / 239$ and $\mathrm{m} / \mathrm{z}=255 / 256$. It should be noted that the complex ions containing sodium $[\mathbf{1}+\mathrm{Na}]^{+}$at $\mathrm{m} / \mathrm{z} 422$ appear also in the spectra of potassium complexes. The reason for this phenomenon is the ubiquity of sodium ions in the used solvents and laboratory glassware. By comparing the intensity of ions $[\mathbf{1}+\mathrm{Na}]^{+}$and $[\mathbf{1}+\mathrm{K}]^{+}$, it appears that the formation of 1:1 complexes as well as dimeric complexes $[2 \cdot \mathbf{1}+\mathrm{M}]^{+}$is preferred in the presence of sulphate ions.In the negative ion mode (TOF MS LD ${ }^{-}$) mainly the signal of an ion at $\mathrm{m} / \mathrm{z} 225(100 \%$ of relative abundance) can be seen, corresponding to the anion obtained by the deprotonation of MALDI matrix [DIT-H]. Because dithranol is used in a great excess in relation to the analyte, other anions are not detected.

To investigate the dissociation of colchicine complexes with sodium and potassium ions in collisional conditions, we performed MALDI TOF MS/MS measurements for precursor ions $[1+\mathrm{Na}]^{+}, m / z 422$ and $[1+\mathrm{K}]^{+}$, $\mathrm{m} / \mathrm{z} 438$ at collision energies of 30,40,50 and $60 \mathrm{eV}$. The data obtained are summarized in Table 3 . There were almost no fragment ions derived from the precursors at the collision energy $\mathrm{CE}=30 \mathrm{eV}$. At the collision energy of $40 \mathrm{eV}$, single fragment ions appear and more profound fragmentation starts at 50-60 eV. As follows from the data obtained, that colchicine complexes of potassium are not prone to collisional dissociation in general, while sodium complexes decompose to form fragments that correspond to previously reported fragments of colchicine [24-26]. Complexes of colchicine with sodium sulfate show a greater resistance to collisions than those with sodium carbonate.

Table 3: Data from MALDI TOF MSMS spectra $\mathrm{LD}^{+}$of colchicine complexes with sodium and potassium carbonates and sulphates $(\mathrm{m} / \mathrm{z}$ values and \% relative abundance)

\begin{tabular}{l|l}
\hline & TOF MSMS LD \\
\hline & of precursor ion $[1+\mathrm{M}]^{+}, \mathrm{M}=\mathrm{Na}, \mathrm{K}$ \\
\hline
\end{tabular}


Human body fluid ions in colchicine complexes ESI MS, MADLI MS

\begin{tabular}{|c|c|c|c|c|}
\hline \multirow{3}{*}{ COMPLEX } & & \multicolumn{3}{|c|}{ collision energy $\mathrm{CE}[\mathrm{eV}]$} \\
\hline & precursor & 40 & 50 & 60 \\
\hline & \multicolumn{4}{|c|}{$\mathrm{m} / \mathrm{z}$ (\% relative abundance) } \\
\hline $1+\mathrm{Na}_{2} \mathrm{CO}_{3} 2$ & 422 & $\begin{array}{c}282 \\
(100)\end{array}$ & $\begin{array}{c}251(75), 225 \\
(100), 149(75)\end{array}$ & - \\
\hline $1+\mathrm{K}_{2} \mathrm{CO}_{3} 3$ & 438 & $\begin{array}{c}149 \\
(100)\end{array}$ & $149(100)$ & - \\
\hline $1+\mathrm{Na}_{2} \mathrm{SO}_{4} 4$ & 422 & $\begin{array}{c}341 \\
(100)\end{array}$ & $267(100)$ & $\begin{array}{c}267(89), 251 \quad(72), \\
224(100), 195 \text { (67), } \\
181 \quad(50)\end{array}$ \\
\hline $\mathbf{1}+\mathrm{K}_{2} \mathrm{SO}_{4} \mathbf{5}$ & 438 & $\begin{array}{c}149 \\
(100)\end{array}$ & $149(100)$ & $265(20), 149(100)$ \\
\hline
\end{tabular}

\subsection{NMR measurements}

The ${ }^{1} \mathrm{H}$ and ${ }^{13} \mathrm{C}$ NMR data for the colchicine complexes 2-7 with sodium, potassium, magnesium and calcium sulphates and sodium and potassium carbonates in $\mathrm{CD}_{3} \mathrm{CN}$ are given in Supporting Information in Table S1 and Table S2. In the ${ }^{1} \mathrm{H}$ NMR spectra of all obtained complexes 2-7, no significant changes were detected after the complexation process. The values of chemical shifts of colchicine complexes with carbonates 2-3 are more or less the same like for respective cations for colchicine complexes with sulphates 4-7. Some changes in chemical shifts of protons on amine group $\mathrm{NH}$ and at $\mathrm{H}-\mathrm{C} 8$ were observed. The slightest changes in chemical shifts of hydrogen appear for amide group and the greatest change in chemical shift of this NH proton is found for colchicine complexes with $\mathrm{Mg}^{2+} \mathbf{6}$ and $\mathrm{Ca}^{2+}$ 7. Apart from these changes, these spectra give no information on the structure of respective complexes. The ${ }^{1} \mathrm{H}$ NMR spectra of colchicine and its complexes with carbonates and sulphates are almost the same, irrespective of different cations and ions (complexes 2-5), which has been observed earlier for other biologically active compounds like monensin, oligomycin and their complexes with colchicine [16, 19-21].

In the ${ }^{13} \mathrm{C}$ NMR spectra of colchicine and its complexes 2-7 some changes in chemical shifts were observed for carbon atoms C-4a, C-7a and carbonyl groups. The chemical shifts of carbon atoms show that both carbonyl groups: at $\mathrm{C}-7$ position (acetamide group) and $\mathrm{C}-9$ in the tropolone ring $\mathrm{C}$ are involved in the coordination process.

\subsection{FT IR measurements}

The FT IR spectra of 2-7 colchicine complexes with monovalent and divalent cations and for comparison the spectrum of colchicine, all in KBr pellets, are shown in Figure $4 \mathrm{a}-\mathrm{c}$ and Table 4. (in the region of carbonyl group) and full FT IR data are given in the Experimental section.

a) colchicine-sodium carbonate $\mathbf{2}$ and colchicine-potassium carbonate $\mathbf{3}$



b) colchicine-sodium sulphate $\mathbf{4}$ and colchicine-potassium sulphate $\mathbf{5}$ 


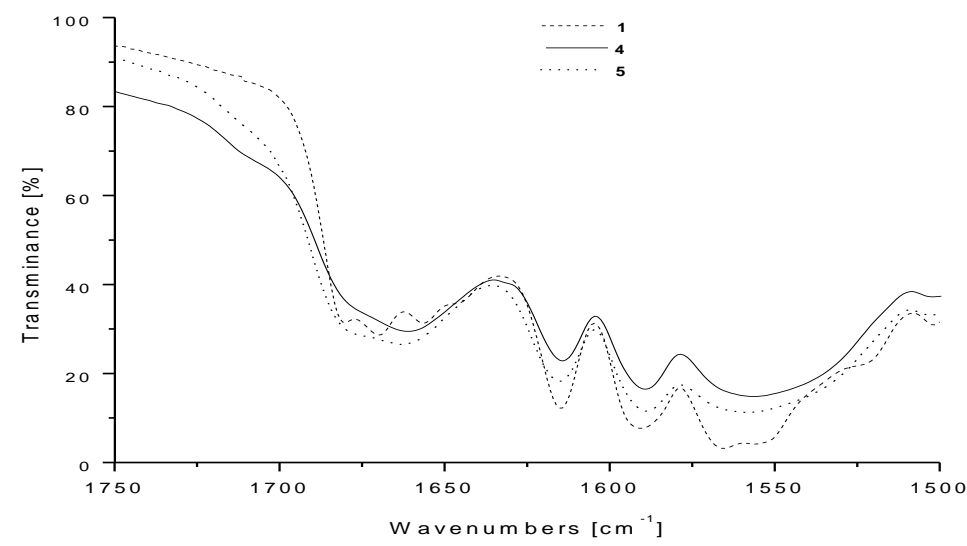

c) colchicine-magnesium sulphate $\mathbf{6}$ and colchicine-calcium sulphate 7

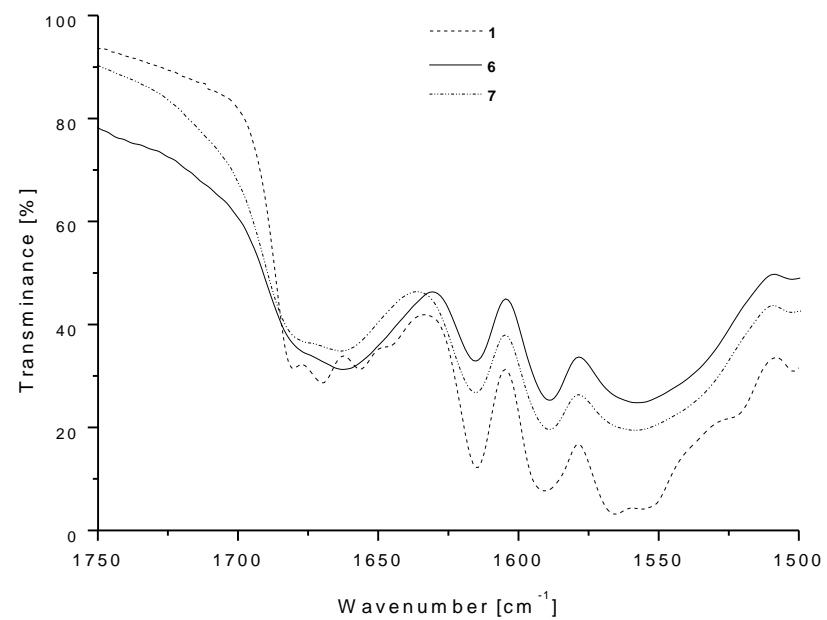

Fig. 4. FT IR spectra of colchicine 1 and its complexes $2-7$ in the range of $1750-1500 \mathrm{~cm}^{-1}$

After the complexation process of colchicine and respective monovalent and divalent cations of sulphates and carbonates, the shapes and intensities of the bands assigned to stretching vibrations have changed. The NH stretching vibrations of colchicine is observed in the FT IR spectrum as a band with a maximum at $3359 \mathrm{~cm}^{-1}$. In the FT IR spectra of colchicine complexes 2-7 the band of stretching vibration of NH is shifted towards lower wavenumbers. In the solid state colchicine exists as monohydrate [41]. The stretching vibrations of the water molecules are observed in the FT IR spectra as a band with a maximum at about $3447 \mathrm{~cm}^{-1}$. The same band is also observed in the spectra of the colchicine complexes with $\mathrm{Na}^{+}, \mathrm{K}^{+}, \mathrm{Mg}^{2+}$ and $\mathrm{Ca}^{2+}$ cations but the maximum of the band is shifted towards lower wavenumbers in comparison to its position in the colchicine 1 spectrum at about 29-33 $\mathrm{cm}^{-1}$ and depends on the kind of cation and anion in the following order $\mathbf{5}=\mathbf{7}<\mathbf{3}<\mathbf{4}$ $<\boldsymbol{2}=\mathbf{6}, \mathrm{K}^{+}\left(\mathrm{K}_{2} \mathrm{SO}_{4}\right)=\mathrm{Ca}^{2+}\left(\mathrm{CaSO}_{4}\right)<\mathrm{K}^{+}\left(\mathrm{K}_{2} \mathrm{CO}_{3}\right)<\mathrm{Na}^{+}\left(\mathrm{Na}_{2} \mathrm{SO}_{4}\right)<\mathrm{Na}^{+}\left(\mathrm{Na}_{2} \mathrm{CO}_{3}\right)=\mathrm{Mg}^{2+}\left(\mathrm{MgSO}_{4}\right)$. FT IR spectra in the region of carbonyl group of colchicine complexes with sodium and potassium carbonates 2,3 and colchicine complexes with sodium and potassium sulphates $\mathbf{4 , 5}$ and of colchicine complexes with magnesium and calcium sulphates 6, 7 are given in Fig 4.a.b.c, respectively. The strongest shift to the lower wavenumbers can be observed for the band assigned to the carbonyl group on ring B from $1680 \mathrm{~cm}^{-1}$ for colchicine 1 to 1658 $\mathrm{cm}^{-1}$ for colchicine complex with potassium carbonate 3 . There were no significant changes in the shifts of the stretching vibration of carbonyl group of tropolone ring $C$ in the spectra of all colchicine complexes 2-7, which means that this part of colchicine molecule is not involved in the complexation process as much as the carbonyl group on tropolone ring $\mathrm{C}$.

Table 4: Wavenumbers of colchicine complexes 2-7 in the region of carbonyl group (in KBr pellets)

\begin{tabular}{cccccccc}
\hline \multirow{2}{*}{ Assignments } & $\mathbf{7}$ Wavenumbers $\left[\mathrm{cm}^{-1}\right]$ \\
\cline { 2 - 8 } & $\mathbf{1}$ & $\mathbf{2}$ & $\mathbf{3}$ & $\mathbf{4}$ & $\mathbf{5}$ & $\mathbf{6}$ & $\mathbf{7}$ \\
\hline $\mathrm{vC}=\mathrm{O}$ & 1680 & 1661 & 1663 & 1662 & 1663 & 1662 & 1658 \\
$\mathrm{vC}=\mathrm{O}$ & 1615 & 1614 & 1615 & 1615 & 1615 & 1615 & 1616 \\
\hline
\end{tabular}


After the complexation process, in the FT IR spectra of all obtained complexes 2-7 the bands assigned to the stretching vibration of $\mathrm{UC}=\mathrm{C}$ at $1670 \mathrm{~cm}^{-1}$ and $1656 \mathrm{~cm}^{-1}$ (observed in the FT IR spectrum of colchicine 1), disappear.

The stretching vibrations of carbonates usually appear as a very strong band in the range of 1450-1410 $\mathrm{cm}^{-1}$ and the second band with medium intensity in the range $880-860 \mathrm{~cm}^{-1}$. This second band position is shifted to lower wavenumbers with increasing of atomic weigh of the cation. This correlation was also observed for complexes 2 with $\mathrm{Na}^{+}$cation $\left(841 \mathrm{~cm}^{-1}\right)$ and 3 with $\mathrm{K}^{+}$cation $\left(832 \mathrm{~cm}^{-1}\right)$. Many carbonates also show absorption in the $750-710 \mathrm{~cm}-1$ region. In addition, the number of bands between $1110 \mathrm{~cm}^{-1}$ and $700 \mathrm{~cm}^{-1}$ increases in most cases from two to five whilst the bonded $\mathrm{OH}$ grouping are evident at $3300 \mathrm{~cm}^{-1}$.

Sulphate anions are responsible for a very strong band corresponding to stretching vibration in the range $1130-1080 \mathrm{~cm}^{-1}$ accompanied by a considerably weaker band in the region $680-610 \mathrm{~cm}^{-1}$. For the calcium sulphate dihydrate salt the strong band was centered at $1140 \mathrm{~cm}^{-1}$ but in the spectrum of the pure calcium sulphate salt a group of these bands was found in this region, which means that both hydration and crystal symmetry may influence the spectra.

\subsection{Theoretical studies}

Eight different interaction schemes in the colchicine complexes with sodium cation suggested by experimental measurements were subjected to further computational studies. Figure 5 presents initial interaction schemes for 1:1 complexes (structures A-C), 2:1 (structures D,E) and 3:1 (structures F-H).

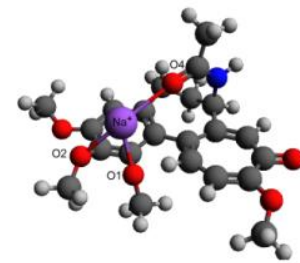

A

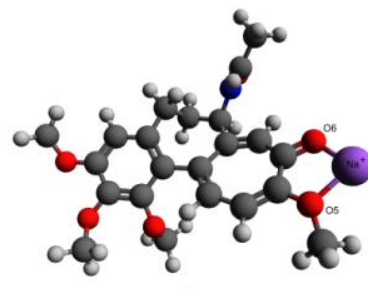

B



C

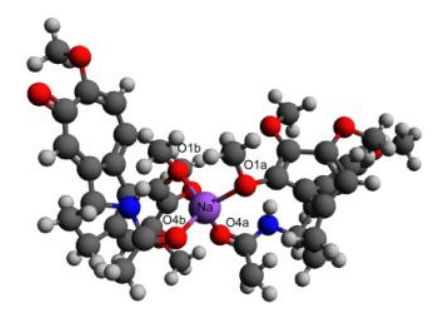

D

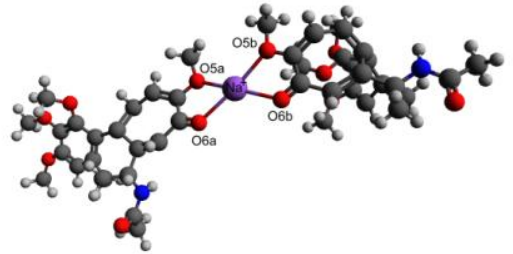

E

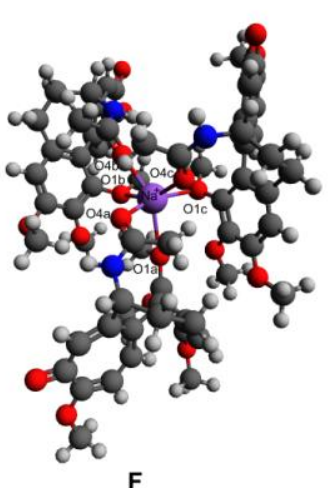

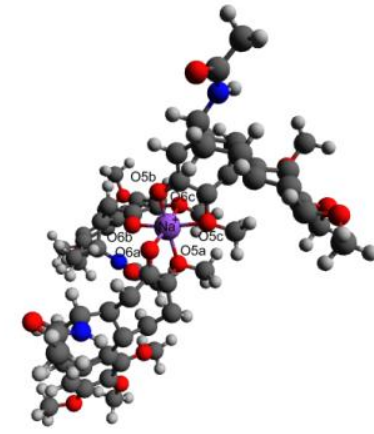

G

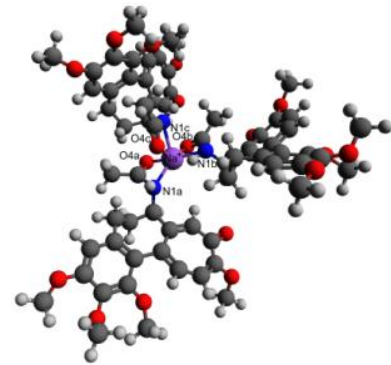

H

Fig. 5. Initial structures for interaction schemes of $1: 1,2: 1$ and $3: 1$ stoichiometry of colchicine complexes with $\mathrm{Na}^{+}$.

The interaction energies calculated for each type of colchicine complexes with sodium cation are shown in Table 5. 
Table 5: The interaction energies (counterpoise corrected and uncorrected) calculated for the studied interaction schemes of colchicine with $\mathrm{Na}^{+}$cation.

\begin{tabular}{ccc}
\hline $\begin{array}{c}\text { Colchicine } \\
\text { complex }\end{array}$ & $\begin{array}{c}\text { Counterpoise } \\
\text { interaction Energy } \\
\text { (uncorrected) } \\
\text { [kcal/mol] }\end{array}$ & $\begin{array}{c}\text { Counterpoise } \\
\text { interaction Energy } \\
\text { (corrected) }[\mathrm{kcal} / \mathrm{mol}]\end{array}$ \\
\hline 1:1 Type $\mathbf{A}$ & -82.7 & -80.3 \\
1:1 Type $\mathbf{B}$ & -68.5 & -67.0 \\
1:1 Type $\mathbf{C}$ & -53.6 & -52.4 \\
2:1 Type $\mathbf{D}$ & -127.2 & -119.4 \\
2:1 Type $\mathbf{E}$ & -117.7 & -114.2 \\
3:1 Type $\mathbf{F}$ & -165.7 & -151.1 \\
3:1 Type $\mathbf{G}$ & -142.1 & -134.1 \\
3:1 Type $\mathbf{H}$ & -144.1 & -133.8 \\
\hline
\end{tabular}

Absolute energy baseline [Hartree]: $\quad-1520.506867^{\mathrm{A}}, \quad-1520.492234^{\mathrm{B}}, \quad-1520.466755^{\mathrm{C}}, \quad-2878.90264^{\mathrm{D}}$, $-2878.887362^{\mathrm{E}},-4237.299946^{\mathrm{F}},-4237.143139^{\mathrm{G}},-4237.244115^{\mathrm{H}}$

For 1:1 stoichiometry complexes of colchicine with sodium cation the most favorable interaction energy ($80.3 \mathrm{kcal} / \mathrm{mol}$ ) had A structure. Other interaction schemes were less energetically favorable (see Figure 6).

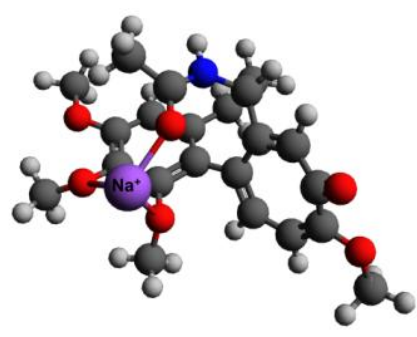

A

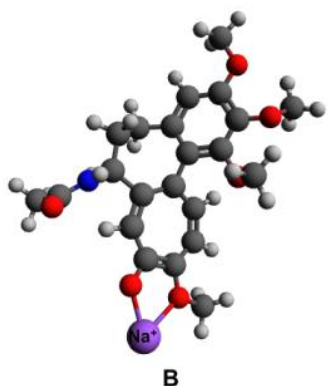

$B$

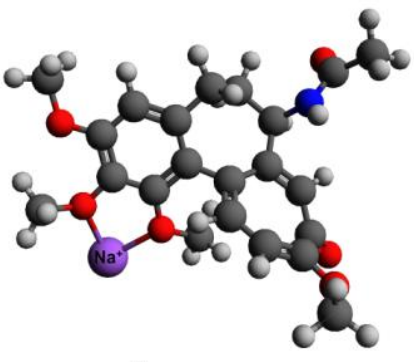

Fig. 6. The optimized structures of 1:1 stoichiometry structures of colchicine with sodium cation.

For the complexes of 2:1 stoichiometry, the most favourable interaction energy $(-119.4 \mathrm{kcal} / \mathrm{mol})$ was found for structure $\mathbf{D}$ which was most probably additionally stabilized by weak interaction between $\mathrm{Na}^{+}$and $\mathrm{O} 1$ colchicine oxygen atom ( $\mathrm{Na} . . \mathrm{O} 1$ distance $2.542 \AA)$. The optimized structures of 2:1 stoichiometry complexes are shown in Figure 7.
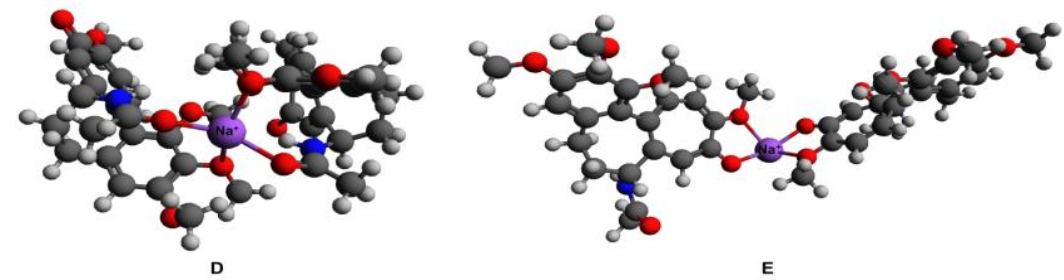

Fig. 7. The optimized structures of 2:1 stoichiometry complexes of colchicine with sodium cation

From among the colchicine structures of 3:1 stoichiometry the most favorable interaction energy $(-151.1$ $\mathrm{kcal} / \mathrm{mol}$ ) was found for $\mathbf{F}$ structure. Two of colchicine ligands coordinated sodium cation via $\mathrm{O} 4$ oxygen atom only but one of colchicine molecule interacted more strongly as it used $\mathrm{O} 1, \mathrm{O} 2$ and $\mathrm{O} 4$ oxygen atoms to bind central $\mathrm{Na}^{+}$cation. An attempt to obtain a structure with $\mathrm{Na}^{+}$coordinated by $\mathrm{N} 1$ nitrogen atom of colchicine failed, because during the optimization the coordination mode was changed to $\mathrm{Na}^{+}$...O instead of the $\mathrm{Na}^{+} \ldots \mathrm{N}$. . The structures of the optimized 3:1 stoichiometry complexes are shown in Figure 8.

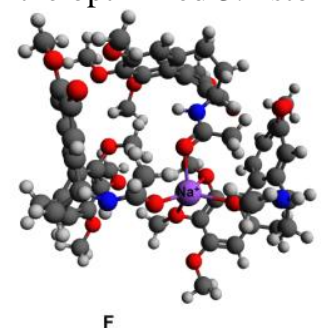

F

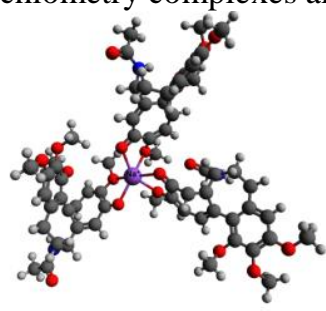

G

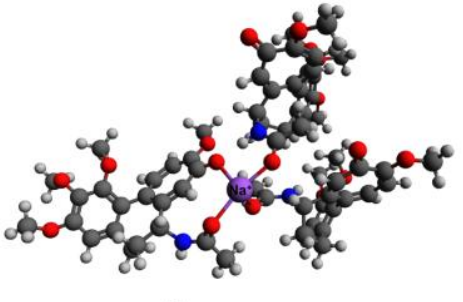


Fig. 8. The optimized structures of 3:1 stoichiometry complexes of colchicine with sodium cation.

Table 6: Selected geometry parameters and calculated Mulliken partial charges for each interaction schemes of colchicine complexes.

\begin{tabular}{|c|c|c|c|c|}
\hline $\begin{array}{l}\text { Colchicine } \\
\text { complex }\end{array}$ & $\begin{array}{l}\text { Sodium cation } \\
\text { partial charge }\left[\mathrm{e}^{-}\right]\end{array}$ & $\begin{array}{l}\text { Coordinat } \\
\text { ing atom }\end{array}$ & $\begin{array}{l}\text { Coordinating } \\
\text { atom partial } \\
\text { charge }\left[\mathrm{e}^{-}\right]\end{array}$ & $\begin{array}{l}\text { Distance between } \\
\text { the coordinating } \\
\text { atom and the } \\
\text { cation }[\AA]\end{array}$ \\
\hline \multirow{3}{*}{ 1:1 Type $\mathbf{A}$} & +0.835 & $\mathrm{O} 4$ & -0.460 & 2.163 \\
\hline & & $\mathrm{O} 1$ & -0.467 & 2.234 \\
\hline & & $\mathrm{O} 2$ & -0.424 & 2.663 \\
\hline \multirow[t]{2}{*}{ 1:1 Type $\mathbf{B}$} & +0.836 & $\mathrm{O5}$ & -0.424 & 2.381 \\
\hline & & O6 & -0.467 & 2.107 \\
\hline \multirow[t]{2}{*}{ 1:1 Type $\mathbf{C}$} & +0.876 & $\mathrm{O} 1$ & -0.506 & 2.255 \\
\hline & & $\mathrm{O} 2$ & -0.526 & 2.179 \\
\hline \multirow[t]{5}{*}{ 2:1 Type $\mathbf{D}$} & +0.636 & $\mathrm{O} 4^{\mathrm{a}}$ & -0.422 & 2.329 \\
\hline & & $\mathrm{O} 1^{\mathrm{a}}$ & -0.415 & 2.542 \\
\hline & & $\mathrm{O} 2^{\mathrm{a}}$ & -0.428 & 2.414 \\
\hline & & $\mathrm{O} 4^{\mathrm{b}}$ & -0.448 & 2.205 \\
\hline & & $\mathrm{O} 2^{\mathrm{b}}$ & -0.424 & 2.626 \\
\hline \multirow[t]{4}{*}{ 2:1 Type $\mathbf{E}$} & +0.775 & $\mathrm{O}^{\mathrm{a}}$ & -0.421 & 2.340 \\
\hline & & $\mathrm{O6}^{\mathrm{a}}$ & -0.475 & 2.202 \\
\hline & & $\mathrm{O}^{\mathrm{b}}$ & -0.420 & 2.344 \\
\hline & & $\mathrm{O}^{\mathrm{b}}$ & -0.475 & 2.196 \\
\hline \multirow[t]{5}{*}{ 3:1 Type $\mathbf{F}$} & +0.596 & $\mathrm{O} 4^{\mathrm{a}}$ & -0.388 & 2.364 \\
\hline & & $\mathrm{O} 1^{\mathrm{a}}$ & -0.420 & 2.485 \\
\hline & & $\mathrm{O} 2^{\mathrm{a}}$ & -0.424 & 2.569 \\
\hline & & $\mathrm{O} 4^{\mathrm{b}}$ & -0.435 & 2.209 \\
\hline & & $\mathrm{O} 4^{\mathrm{c}}$ & -0.420 & 2.363 \\
\hline \multirow[t]{6}{*}{ 3:1 Type $\mathbf{G}$} & +0.669 & $\mathrm{O}^{\mathrm{a}}$ & -0.405 & 2.401 \\
\hline & & $\mathrm{O6}^{\mathrm{a}}$ & -0.416 & 2.340 \\
\hline & & $\mathrm{O}^{\mathrm{b}}$ & -0.428 & 2.379 \\
\hline & & $\mathrm{O}^{\mathrm{b}}$ & -0.371 & 2.339 \\
\hline & & $\mathrm{O} 5^{\mathrm{c}}$ & -0.401 & 2.388 \\
\hline & & $\mathrm{O}^{\mathrm{c}}$ & -0.297 & 2.395 \\
\hline \multirow[t]{4}{*}{ 3:1 Type $\mathbf{H}$} & +0.683 & $\mathrm{O} 4^{\mathrm{a}}$ & -0.421 & 2.344 \\
\hline & & $\mathrm{O}^{\mathrm{a}}$ & -0.449 & 2.379 \\
\hline & & $\mathrm{O} 4^{\mathrm{b}}$ & -0.501 & 2.209 \\
\hline & & $\mathrm{O} 4^{\mathrm{c}}$ & -0.437 & 2.299 \\
\hline
\end{tabular}

Selected interatomic distances and Mulliken point charges are shown in Table 6. Amongst the most

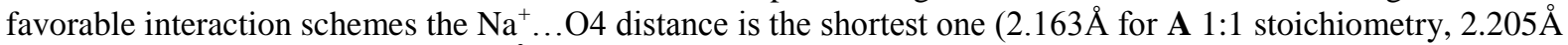
for D 2:1 stoichiometry and 2.209 $\AA$ for F 3:1 stoichiometry) suggesting that it is the strongest interaction between the central $\mathrm{Na}^{+}$cation and colchicine ligand. Mulliken partial charges on sodium cation varied from $+0.595 \mathrm{e}^{-}$in structure $\mathbf{F}$ of 3:1 stoichiometry to $+0.876 \mathrm{e}^{-}$in structure $\mathbf{C}$ of 1:1 stoichiometry. The Mulliken point charges calculated for coordinating oxygen atoms varied form $-0.526 \mathrm{e}^{-}$for $\mathrm{O} 2$ oxygen atom in $\mathbf{C}$ structure of 1:1 stoichiometry to $-0.297 \mathrm{e}^{-}$for $\mathrm{O} 6$ oxygen atom in 3:1 stoichiometry $\mathbf{G}$ structure.

\subsection{Fungicidal activity of colchicine complexes}

Colchicine binds with lower affinity to fungal tubulins as compared to mammalian tubulins [40]. Colchicine has been tested previously against antifungal activity for Aspergillus niger, Allomyces javanicus, Aspergillus spp., Butrylis cinerea, Caprinus radians, Diaparhte perniciosa, Mucor sp., Penicillium notatum, Psilocyte semilanceolata, Dia and Saccharomyces cerversiae, Candida [41, 42]. In some cases changes were not observed but in for others were, for example prevention of candida formation or inhibition of fungi growth. 
Colchicine is effective in gout therapy in the treatment of acute gout. It has been established that gout in human body in most cases is induced by the fungal species Ustilago maydis, Chaetomium trilaterale, Saccharomyces cerversiae and yeast Candida utilis and fungal metabolites cyclosporine, ergotamine and penicillin. Beer and wine are produced with involvement of fermentations of Saccharomyces cerversiae so drinking them is tantamount to drinking a fungal culture. Moreover in beer there are large amounts of uric acid which cause tophi [42]. Colchicine significantly inhibited the fungicidal activity of neutrophils against Penicillium marneffei in dose-dependent manner and this inhibition was not due to its cytotoxic effect [43].

In this study the properties of derivatives of colchicine against microfungi were analyzed using the bioautography-TLC method. This method belongs to microbiological screening tests commonly used for identification of fungistatic properties of compounds. All salts constituting complexes with colchicine were also tested and they were found not to show antifungal properties.

The results for the new derivatives of colchicine are presented in Table 7. The fungal mycelium growing all over the control plates evidenced that it was in good condition during the test. The results permit a conclusion that the antifungal properties of some new complexes of colchicine may be potentially useful for controlling moulds. Bioautography combined with TLC showed that the growth of all Aspergillus strains was inhibited by complex 4 forming clear inhibition zones, though the other species exhibited weak growth. The tested compounds 3, 5, 7 in the first days of the test, inhibited the growth of mycelium A. niger but in the following days of the test they were inactivated (not shown in the table). Derivative $\mathbf{3}$ besides showing fungistatic properties against $P$. variotii also in the first days of the test inhibited the growth of $A$. versicolor. No antifungal properties were observed for compound 2. Moreover, the above compounds also complex 6 showed very high fungistatic activity against $P$. funiculosum and in addition inhibited the growth of $A$. versicolor and $P$. variotti in the first days of observation.

Table 7: The results of bioassay tests against microfungi

\begin{tabular}{ccccc}
\hline $\begin{array}{l}\text { Colchicine and } \\
\text { complexes }\end{array}$ & \multicolumn{3}{c}{ Fungal species } \\
\hline \multicolumn{1}{c}{ A. niger } & A. versicolor & P. variotii & P. funiculosum \\
\hline $\mathbf{2}$ & + & + & + & + \\
\hline $\mathbf{3}$ & + & + & + & + \\
\hline $\mathbf{4}$ & + & + & + & + \\
\hline $\mathbf{5}$ & - & - & + & + \\
\hline $\mathbf{6}$ & + & + & + & + \\
\hline $\mathbf{7}$ & + & + & + & + \\
\hline & + & + & + \\
\hline
\end{tabular}

MICs of colchicine complexes $\mathbf{3}$ and $\mathbf{6}$ against $C$. puteana, $P$. placenta and C. versicolor were determined by the agar dilution method. The MIC was defined as the lowest concentration of a given agent at which no visible growth of fungi was noted or the lowest concentration that inhibited more than $80 \%$ of growth. The in-vitro susceptibility testing using complexes of colchicine is shown in Table 8. It has been proven that compound $\mathbf{3}$ has inhibitory effects against white rot fungi $P$. placenta and $C$. versicolor and also against brown rot fungus $C$. puteana. Compound 6 showed only fungistatic properties against one fungus $P$. placenta. Among the Basidiomycota fungi, the MICs of compound 3 were within the range of $0.1-0.01 \mathrm{~g} / \mathrm{mL}$ for $C$. puteana and $C$. versicolor while both compounds 3 and 6 had a MIC equal to $0.1 \mathrm{~g} / \mathrm{mL}$ for P. placenta. Comparison of MICs values for the fungi tested revealed a difference in the tolerance against the tested compounds. $P$. placenta showed greater tolerance with MICs being one order of concentration magnitude higher than the values determined for $C$. puteana and $C$. versicolor within the selected concentration range for compound 3. $P$. placenta did not show such a high resistance as above towards compound 6 , while the other fungi proved to be more resistant to this compound.

Table 8: The results of bioassay tests for minimal inhibitory concentration (MIC) against Basidiomycota fungi Antifungal index of tested compounds against

\begin{tabular}{cccccc}
\multirow{2}{*}{ Compound } & \multirow{2}{*}{ Fungi } & \multicolumn{4}{c}{ Basidiomycota fungi $^{\mathrm{a}}$} \\
\cline { 3 - 5 } & & 0.1 & 0.01 & 0.001 & 0.0001 \\
\cline { 3 - 5 } & & $86.90 \pm 4.40$ & $71.22 \pm 9.80$ & $27.26 \pm 4.77$ & $24.02 \pm 5.94$ \\
\hline 3
\end{tabular}




\begin{tabular}{clcccc} 
& C. puteana & $100 \pm 0.00$ & $50.34 \pm 3.79$ & $34.32 \pm 6.81$ & $32.04 \pm 5.86$ \\
\cline { 2 - 6 } & C. versicolor & $100 \pm 0.00$ & $45.21 \pm 3.29$ & $23.57 \pm 2.72$ & $18.72 \pm 9.20$ \\
\hline \multirow{6}{*}{6} & P. placenta & $100 \pm 0.00$ & $0.56 \pm 0.23$ & $0.00 \pm 0.00$ & $0.00 \pm 0.00$ \\
\cline { 2 - 6 } & C. puteana & $56.06 \pm 3.51$ & $14.79 \pm 1.69$ & $16.91 \pm 1.28$ & $10.91 \pm 1.29$ \\
\cline { 2 - 6 } & C. versicolor & $26.86 \pm 7.20$ & $1.56 \pm 0.53$ & $0.57 \pm 0.50$ & $0.00 \pm 0.00$ \\
\hline
\end{tabular}

${ }^{a}$ Data are presented as the means \pm relative standard deviation (RSD) of five determinations

On the basis of the results from antifungal assays we can conclude that fungistatic activity of the new complexes of colchicine may be potentially useful for controlling the growth of fungi. The tested compounds inhibited the growth of some types of microfungi, but there was no compound active against all tested species of moulds. However, complex $\mathbf{3}$ demonstrated fungistatic properties against rot fungi belonging to the phylum Basidiomycota. Nevertheless, the approach developed in the study could be a useful way to identify a new class of antifungal agents.

\section{CONCLUSION}

Series of new colchicine complexes with monovalent and divalent metal cations of carbonates and sulfates were obtained and described by spectral analysis. In the present work it was found that colchicine can form stable complexes with ions of human body fluids like: $\mathrm{Na}^{+}, \mathrm{K}^{+}, \mathrm{Ca}^{2+}$ and $\mathrm{Mg}^{2+}$. In the our previous work it was found that colchicine forms complexes with lithium, sodium and potassium iodides and perchlorates mainly in stoichiometry 1:1 and less preferable in 2: 1 stoichiometry. In comparison to the in present study it was found that colchicine with sodium, potassium, magnesium and calcium sulfates and sodium, potassium carbonates can form much more complicated complexes in stoichiometry $2: 1$ and for complex with sodium sulphate $3: 1$ and 2:1:1. Moreover, sulphate anions were also involved in complexation process.

Quantum-mechanical calculations helped indicate which colchicine atoms are involved in coordinating sodium cation. It appears that one colchicine molecule is particularly strongly bound to $\mathrm{Na}^{+}$and interacts via $\mathrm{O} 4, \mathrm{O} 1$ and $\mathrm{O} 2$ oxygen atoms. Moreover, our calculations suggest that $\mathrm{Na}^{+} \ldots \mathrm{O} 4$ interaction is energetically favored for complexes stoichiometry of 1:1, 2:1 and 3:1. It also seems that nitrogen atom of colchicine is not favored as a donor when compared with oxygen atoms.

New colchicine complexes show fungicidal activity against selected species of moulds, in the future they may be potentially useful for controlling the growth of fungi.

Acknowledgment

This research was supported in part by grand PL-Grid Infrastructure.

\section{REFERENCES}

[1] A. Brossi, H.J. Yeh, M. Chrzanowska, J. Wolff, E. Hamel, C.M. Lin, F .Quin, M. Suffness and J. Silverton, Colchicine and its analogues: Recent findings, Med. Res. Rev. 8, 1988, 77-87.

[2] M. Klintscher, C. Beham - Schmidt, H. Radner, G. Henning, P. Roll, Colchicine poisoning by accidental ingestion of meadow saffron (Colchicum autumnale): pathological and medicolegal aspects, Forensic Sci. Int. 106, 1999, 191-198.

[3] J.W. Cook, J.D. Loudon, The alkaloids vol. 2 (Academic Press, New York, 1952).

[4] M. Schonharting, G. Mende, G. Siebert, Hoppe - Seyler's Zeitschrift für physiologische Chemie. 355, 1974, 1991-1999.

[5] F. Roubille, E. Kritikou, D. Busseuil, S. Barrère-Lemaire and J.C. Tardif, Colchicine: An Old Wine in a New Bottle? Anti-Inflam \& Anti-Allergy. Agents Med. Chem. 12, 2013, 14-23.

[6] D. O'Neil, Blood Components (Palomar College. Tuskegee University 2013).

[7] F. Lang. Mechanisms and Significance of Cell Volume Regulation, J Am Coll Nutr. 26, 2007, 5 613S$623 \mathrm{~S}$.

[8] M.J. Berridge. Elementary and global aspects of calcium signalling J. Physiol. Lond. 499, 1997, (Pt 2): 291-306.

[9] U. Kikkawa, A. Kishimoto and Y. Nishizuka. The protein kinase C family: heterogeneity and its implications. Annu. Rev. Biochem. 58, 1989, 31-44.

[10] S.N. Orlov and P. Hamet. Intracellular monovalent ions as second messengers. J. Membr. Biol. 210,2006, $161-172$.

[11] Lodish, F. Harvey Molecular cell biology. (Scientific American Books New York 1999).

[12] D.S. Goodsell, Inside a living cell, Trends Biochem. Sci. 16, 1991, 203-206. 
[13] B. Bhattacharyya and J. Wolff, Anion-Induced Increases in the Rate of Colchicine Binding to Tubulin, Biochemistry 15, 1976, 2283-2288.

[14] M. F. Mackay, R. W. Gable, J. D. Morrison and L. O. Satzke, Structure of Hydrated Copper(II) Colchiceine, Austr. J. Chem. 52,1999, 333-338.

[15] J. Kurek, Wł. Boczoń, P. Przybylski and B. Brzeziński, ESI MS, spectroscopic and PM5 semiempirical studies of Colchicine complexes with lithium, sodium and potassium salts, J. Mol. Struct. 846, 2007, 1322.

[16] E. Bodoki, D. Bogdan, R. Săndulescu, $A B$ initio study of the Na-colchicine positively charged complex, Farmacia 63, 2015, 4-10.

[17] B. Gierczyk, G. Schroeder, P. Przybylski, B. Brzeziński, F. Bartl and G. Zundel, ESI MS, NMR and PM5 semiempirical studies of oligomycin A and its complexes with $\mathrm{Li}^{+}$and $\mathrm{Na}^{+}$cations, J. Mol. Struct. 738, 2005, 261-269.

[18] A. Huczyński, P. Przybylski, B. Brzeziński and F. Bartl, Monensin A methyl ester complexes with $\mathrm{Li}^{+}$, $\mathrm{Na}^{+}$, and $\mathrm{K}^{+}$cations studied by ESI-MS, ${ }^{1} \mathrm{H}-$ and ${ }^{13} \mathrm{C}-\mathrm{NMR}, \mathrm{FTIR}$, as well as PM5 semiempirical method, Biopolymers 81, 2006, 282-289.

[19] A. Huczyński, P. Przybylski, B. Brzeziński and F. Bartl, Spectroscopic, mass spectrometry, and semiempirical investigation of a new ester of Monensin A with ethylene glycol and its complexes with monovalent metal cations, Biopolymers 82, 2006, 491-499.

[20] A. Huczyński, P. Przybylski, B. Brzeziński and F. Bartl, Spectroscopic and Semiempirical Studies of a Proton Channel Formed by the Methyl Ester of Monensin A, J. Phys. Chem. B 110, 2006, 15615-15621.

[21] A. Huczyński, D. Michalak, P. Przybylski, B. Brzeziński and F. Bartl, Monensin A benzyl ester and its complexes with monovalent metal cations studied by spectroscopic, mass spectrometry and semiempirical methods, J. Mol. Struct. 797, 2006, 99-105.

[22] I. M. Choma and E.M. Grzelak, Bioautography detection in thin-layer chromatography, Journal of Chromatography A. 1218, 2011, 2684-2689.

[23] A. Vinnersten and S. Larsson, Colchicine is still a chemical marker for the expanded Colchicaceae, Biochem. System. Ecol. 38, 2010, 1193-1198.

[24] W. Li, Y. Sun, J. F. Fitzloff and R. B. van Breemen, Evaluation of Commercial Ginkgo and Echinacea Dietary Supplements for Colchicine Using Liquid Chromatography-Tandem Mass Spectrometry, Chem. Res. Toxicol. 15, 2002, 1174-1178.

[25] J. Kurek, Z. Nowakowska and G. Bartkowiak, Mass Spectrometric Study of Colchicine and its Synthetic Derivatives 10-Alkylthiocolchicines Acta Chemica Slovenica, 62, 2015, 605-616.

[26] Y. Zhao and D.G. Truhlar, The M06 suite of density functionals for main group thermochemistry, thermochemical kinetics, noncovalent interactions, excited states, and transition elements: two new functionals and systematic testing of four M06-class functionals and 12 other functionals, Theor. Chem. Acc. 120, 2008, 215-221.

[27] T.H. Dunning Jr. and P.J. Hay, Modern Theoretical Chemistry vol. 3 (Plenum, New York, 1976).

[28] R. Bregier-Jarzębowska, K. Malczewska-Jaskóła, W. Jankowski, B. Jasiewicz, M. Hoffmann and A. Gąsowska, Experimental and quantum-chemical studies of anabasine complexes with copper(II) and zinc(II) ions, Polyhedron. 85, 2015, 841-848.

[29] K. Malczewska-Jaskóła, W. Jankowski, B. Warżajtis, B. Jasiewicz, M. Hoffmann and U. Rychlewska, Chalcogenated (S)-(-)-nicotine derivatives as chiral linkers for 1D coordination polymers, Polyhedron. 100, 2015, 404-411.

[30] [31] R.S. Mulliken, Population Analysis on LCAO-MO Molecular Wave Functions. Electronic J. Chem. Phys. 23, 1955, 1833-1840.

[31] A. Roy, R. Prasad, S. Auluck and A. Garg, First-principles calculations of Born effective charges and spontaneous polarization of ferroelectric bismuth titanate J. Phys. Condens. Matter Inst. Phys. J. 22, 2010, 165902-165910.

[32] C.K. Kim, A. Feldman, D. Horowitz and R.M. Waxler, Temperature dependence of Szigeti effective charge of alkali halides Solid State Commun. 25, 1978, 397-399.

[33] K.B.W. Curt and M. Breneman, Determining Atom-Centered Monopoles from Molecular Electrostatic Potentials. The Need for High Sampling Density in Formamide Conformational Analysis, J. Comput. Chem. 11, 1990, 361-373.

[34] S.F. Boys and F. Bernardi, The calculation of small molecular interactions by the differences of separate total energies. Some procedures with reduced errors, Mol. Phys. 19, 1970, 553-566.

[35] S. Simon, M. Duran and J.J. Dannenberg How does basis set superposition error change the potential surfaces for hydrogen-bonded dimers? J. Chem. Phys. 105, 1996, 11024-11031.

[36] M.J. Frisch, G.W. Trucks, H.B. Schlegel, G.E. Scuseria, M.A. Robb, J.R. Cheeseman, G. Scalmani, V. Barone, B. Mennucci, G.A. Petersson, H. Nakatsuji, M. Caricato, X. Li, H.P. Hratchian, A.F. Izmaylov, J. 
Bloino, G. Zheng, J.L. Sonnenberg, M. Hada, M. Ehara, K. Toyota, R. Fukuda, J. Hasegawa, M. Ishida, T. Nakajima, Y. Honda, O. Kitao, H. Nakai, T. Vreven, J.A. Montgomery Jr., J.E. Peralta, F. Ogliaro, M. Bearpark, J.J. Heyd, E. Brothers, K.N. Kudin, V.N. Staroverov, R. Kobayashi, J. Normand, K. Raghavachari, A. Rendell, J.C. Burant, S.S. Iyengar, J. Tomasi, M. Cossi, N. Rega, N.J. Millam, M. Klene, J.E. Knox, J.B. Cross, V. Bakken, C. Adamo, J. Jaramillo, R. Gomperts, R.E. Stratmann, O. Yazyev, A.J. Austin, R. Cammi, C. Pomelli, J.W. Ochterski, R.L. Martin, K. Morokuma, V.G. Zakrzewski, G.A. Voth, P. Salvador, J.J. Dannenberg, S. Dapprich, A.D. Daniels, O. Farkas, J.B. Foresman, J.V. Ortiz, J. Cioslowski, D.J. Fox, Gaussian 09, Revision A.1, Gaussian, Inc., Wallingford, CT, 2009.

[37] G. Cofta, A.K. Przybył, S. Głogowski and E. Napierała. Laboratory Screening Tests with Cytisine and Its Derivatives for Protection Against Mould.Foresty Wood Technol. 63, 2008, 137-143

[38] D.J. Morrrison, Preliminary examination of the crystal structures of colchiceine and its copper salt, Acta Cryst. 4, 1951, 69.

[39] P. V. Gullo, Discovery of Novel Natural Products with Therapeutic Potential (Newnes 2013)

[40] K. Mikanagi Purine and Pyrimidine Metabolism in Man VI: Part A: Clinical and Molecular Biology, (Springer Science \& Business Media, 2012).

[41] A. V. Costantini, The fungal etiology of gout and hyperuricemia: the antifungal mode of action of colchicine, Bio Medical Reviews 1, 1992, 47-52.

[42] N. Kudeken, K. Kawakami and A. Saito, Mechanisms of the in vitro fungicidal effects of human neutrophils against Penicillium marneffei induced by granulocyte-macrophage colony-stimulating factor (GM-CSF), Clin Exp Immunol., 119, 2000, 472-478. 